\title{
Synthesis of Spiro-Pyrrolidinyloxindoles by Oxidative Rearrangement of $N$-Acyltetrahydro- $\beta$-carbolines Using an Oxone/Aqueous Acetone Mixture
}

\author{
Luisa L. Marçal ${ }^{a}$ and Simon J. Garden ${ }^{\circledR *, a}$ \\ ${ }^{a}$ Instituto de Química, Universidade Federal do Rio de Janeiro, Centro de Tecnologia, Bloco A, \\ Cidade Universitária, Ilha do Fundão, 21949-909 Rio de Janeiro-RJ, Brazil
}

\begin{abstract}
Spiro-pyrrolidinyl-2-oxindoles were prepared by the oxidative rearrangement of $N^{a}$-acetyl$1,2,3,4$-tetrahydro- $\beta$-carbolines (THBC) using dimethyldioxirane generated in situ. The $N^{a}$ acetyl THBC substrates were obtained by Pictet-Spengler and acyl-Pictet-Spengler reactions of $L$-tryptophan methyl ester, followed by $N^{a}$-acetylation. The stereoselectivity of the oxidative rearrangement was evaluated and 2D nuclear magnetic resonance (NMR) was used to determine the stereochemistry of the oxindole products relative to $L$-tryptophan. Density functional theory calculations were consistent with a face selective, substrate controlled, epoxidation of the indolic double bond. The calculations indicated that the resulting epoxide would readily rearrange at room temperature via a concerted ring opening/ring contraction process to give the 3 -substituted2-oxindole.
\end{abstract}

Keywords: concerted oxidative rearrangement, dimethyl dioxirane, spiropyrrolidinyl2-oxindole natural products

\section{Introduction}

The structural complexity and the biological activity of natural products containing a spiro-cyclic-oxindole ring system, ${ }^{1,2}$ such as gelsemine, ${ }^{3}$ paraherquamides ${ }^{4}$ and spiropyrrolidinyloxindoles (for example (Figure 1): horsfiline, ${ }^{5}$ coerulescine, ${ }^{6}$ elacomine,${ }^{7}$ rhynchophylline,${ }^{8}$ pteropodine,${ }^{9}$ chitosenine, ${ }^{10,11}$ alstonisine, ${ }^{12}$ spirotryprostatins, ${ }^{13}$ and strychnofoline $)^{14}$ have attracted a great deal of interest over the past few decades. These and related compounds have been a driving force for the development of synthetic methods for the obtention of spiro-cyclic-oxindoles and the investigation of their biological properties. ${ }^{15-25}$

The intense scientific interest has resulted in the discovery of synthetic spiro-pyrrolidinyloxindoles that are enhancers of the cellular actions of latrunculin $\mathrm{B},{ }^{26}$ which interfere with microtubule polymerization, ${ }^{27}$ or are potent MDM2 inhibitors ${ }^{28}$ with sub-nanomolar inhibitor $\left(\mathrm{K}_{\mathrm{i}}\right)$ constants that have been advanced through to clinical trials (Figure 1). ${ }^{29}$

Marti and Carreira, ${ }^{16}$ as well as Galliford and Scheidt, ${ }^{1}$ have classified different generalized synthetic strategies for the synthesis of spiro-pyrrolidinyloxindoles. Amongst the strategies, the oxidative rearrangement of indolic compounds has attracted considerable attention and

*e-mail: garden@iq.ufrj.br a diverse range of oxidants can be used to promote the reaction as exemplified by the following recent examples: $t$-BuOCl, ${ }^{11,30-42} \mathrm{~N}$-chlorosuccinimide (NCS), ${ }^{43} \mathrm{~N}$-bromosuccinimide (NBS), ${ }^{44}$ dibromodimethylhydantoin, ${ }^{45}$ oxaziridines, ${ }^{32,35,46-58}$ dimethyl dioxirane (DMD), ${ }^{32,35,47,59-65}$ trifluoroperacetic acid, ${ }^{66}$ meta-chloroperoxybenzoic acid (mCPBA), ${ }^{67}$ a chiral aspartyl peptide peracid, ${ }^{68} \mathrm{H}_{2} \mathrm{O}_{2}{ }^{69}$ selectfluor, ${ }^{70} \mathrm{XeF}_{2}{ }^{33,71}$ $\mathrm{Pb}(\mathrm{OAc})_{4},{ }^{41} \mathrm{OsO}_{4},{ }^{72}$ or by bioconversion. ${ }^{73}$

In a general manner, the oxidative rearrangement of 2,3-disubstituted indoles to give 3,3-disubstituted2-oxindoles or 2,2-disubstituted indoxyls occurs via formation of a 3-substituted indolenine derivative (Scheme 1). This intermediate is often isolated or treated in situ with acids or bases. The preferential formation of either the 2-oxindole or the indoxyl product depends upon which substituent has a greater propensity to migrate and/ or upon the reaction conditions. ${ }^{30,35-37,74-80}$

In contrast, Zhang and Foote ${ }^{81}$ reported the formation of $\mathrm{N}$-acylindole epoxides at sub-zero temperatures as characterized by nuclear magnetic resonance (NMR) when $\mathrm{N}$-acylindole derivatives were oxidized with an isolated acetone solution of DMD. At room temperature, the $\mathrm{N}$-acylindole epoxides spontaneously rearranged to 2-oxindole and/or indoxyl derivatives depending upon the nature of the substituents. ${ }^{81}$ In a similar fashion, Adam et al. ${ }^{82}$ found that the 1-acetylcyclopent[2,3]indole 
<smiles>C=CC12CC3OCCC3(C3CCC1C31C(=O)Nc3ccccc31)N(C)C2</smiles>

Gelsemine

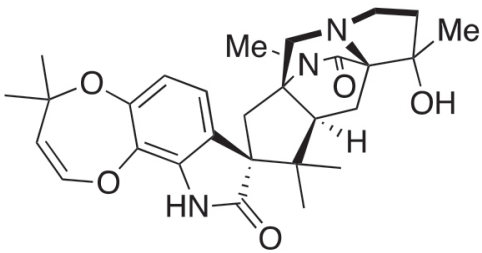

Paraherquamide A<smiles>CC[C@H]1CN2CC[C@@]3(C(=O)Nc4ccccc43)[C@@H]2C[C@@H]1/C(=C\OC)C(=O)OC</smiles>

Rhynchophylline<smiles>COC(=O)C1=CO[C@@H](C)[C@H]2CN3CC[C@]4(C(=O)Nc5ccccc54)[C@H]3C[C@H]12</smiles>

Pteropodine<smiles>[X]c1ccc2c(c1)[C@]1(CCN(C)C1)C(=O)N2</smiles>

Coerulescine $\mathrm{X}=\mathrm{H}$

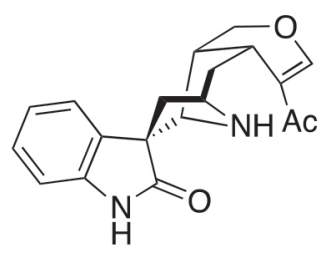

Alstonisine<smiles>CC(C)C1NCC[C@]12C(=O)Nc1cc(O)ccc12</smiles>

(+)-Elacomine

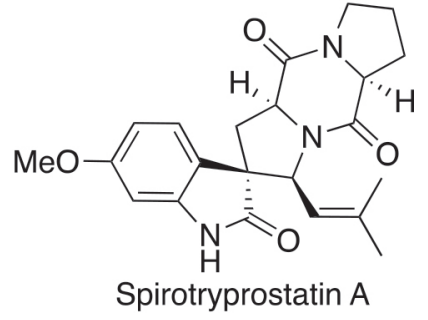<smiles>C=C[C@H]1CN2CC[C@@]3(C(=O)Nc4cc(O)ccc43)[C@@H]2C[C@H]1CC1NCCc2c1[nH]c1ccccc21</smiles>

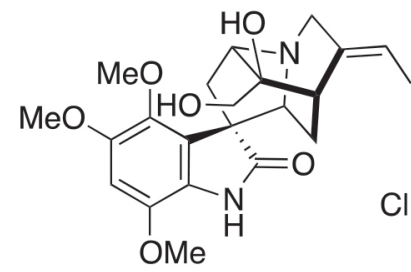

Chitosenine

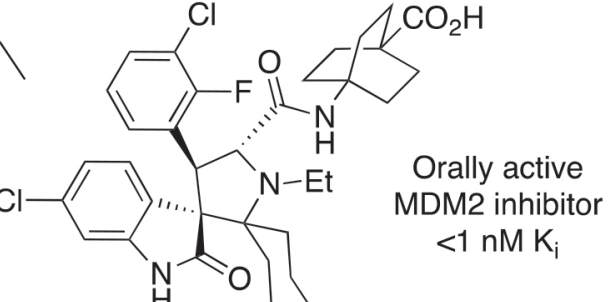

Figure 1. The structures of gelsemine and paraherquamide $A$ and examples of naturally occurring spiro-pyrrolidinyloxindoles and a synthetic MDM2 inhibitor.

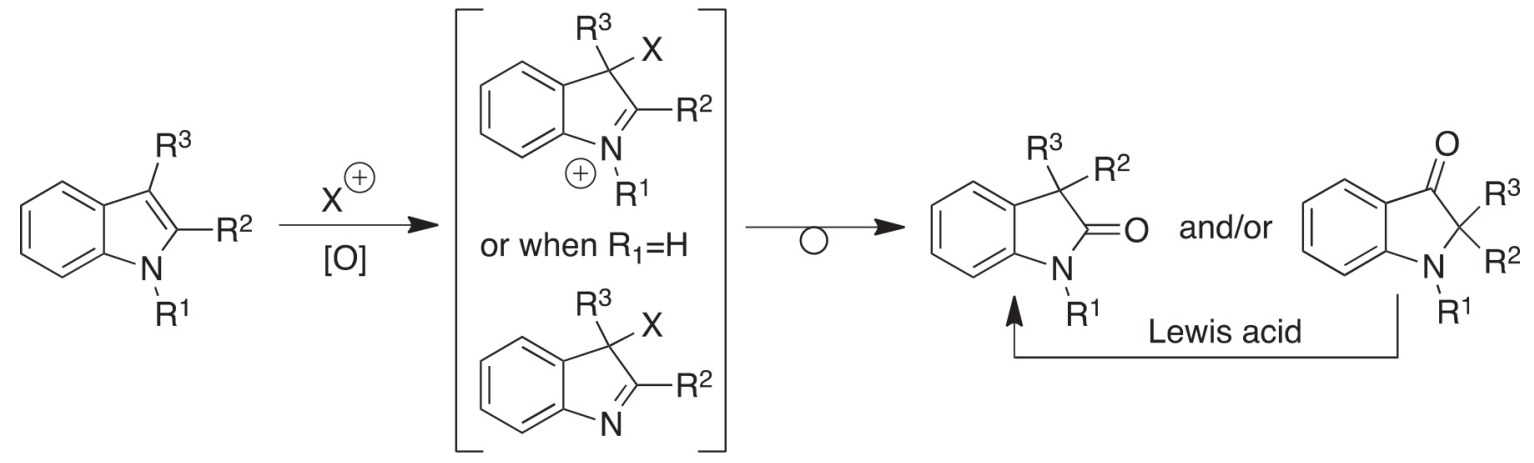

Scheme 1. Oxidation of substituted indoles to give 2-oxindole or indoxyl products.

2,3-epoxide was stable at room temperature for days and they characterized the structure of this compound by single crystal X-ray diffraction.

The present study details the use of DMD, generated in situ, for the oxidative rearrangement of $N^{a}$-acetyl$1,2,3,4$-tetrahydro- $\beta$-carbolines ( $N^{a}$-AcTHBC), prepared from $L$-tryptophan, to give spiro-pyrrolidinyloxindole derivatives without the observed formation of a 3-substituted indolinine derivative (Scheme 2). Initial studies of the oxidation of some acetylated tetrahydro- $\beta$-carbolines using DMD were presented few years ago, ${ }^{83}$ whilst Martin and co-workers ${ }^{32,65}$ and Sarpong and co-workers ${ }^{59,61}$ have more recently employed DMD for the oxidative rearrangement of $N^{a}$-Boc-hydrocarbazole derivatives as part of a strategy towards the total synthesis of citrinadins and citrinalin B. In developing upon the initial studies we have applied the in situ generation of DMD to the oxidative rearrangement of tetrahydrocarboline derivatives (we cannot rule out the possibility that the actual oxidant is in fact an adduct between $\mathrm{KHSO}_{5}$ and acetone, the same adduct which gives rise to DMD). The diastereoselectivity of the rearrangements was qualitatively assessed by the chromatographic separation of the diastereoisomers. The stereochemistry, relative to $L$-tryptophan, was determined from the analysis of the respective nuclear Overhauser effect spectra (NOESY) after assignment of all ${ }^{1} \mathrm{H}$ and ${ }^{13} \mathrm{C}$ signals using two-dimensional (2D) NMR spectra.

\section{Results and Discussion}

Initially, the oxidation of the indole derivatives 4-7 using DMD generated in situ from $\mathrm{NaHCO}_{3}$ and oxone 


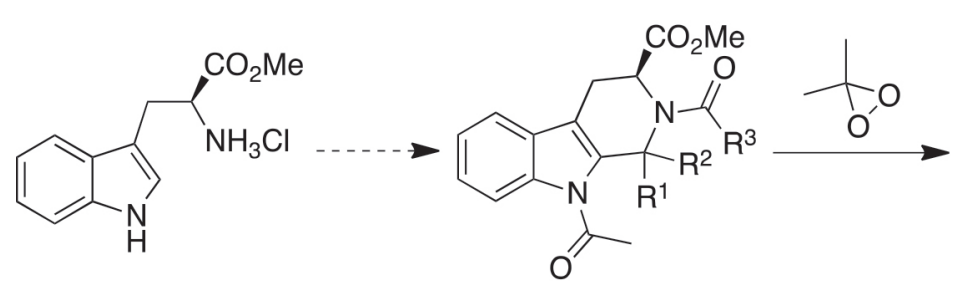

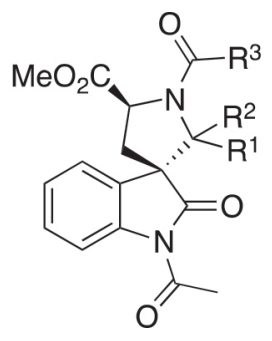

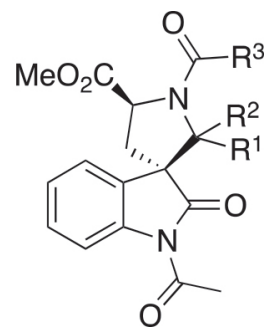

Scheme 2. Synthesis of spiro-pyrrolidinyloxindoles by oxidative rearrangement of $N$-AcTHBCs, derived from $L$-tryptophan methyl ester, using DMD.

in $\mathrm{H}_{2} \mathrm{O} /$ acetone $(1 / 1 \mathrm{v} / \mathrm{v})$ was investigated (Scheme 3). ${ }^{84}$ Whereas the oxidation of $\mathbf{4}$ gave a complex mixture, the oxidation of $\mathbf{5}$ readily provided the $N$-formylkynurenine derivative $8(60 \%)$ and the oxidation of $\mathbf{6}$ gave the tetrahydrobenzazonine-2,7-dione $\mathbf{9}(63 \%)$. These reactions were performed using one mole equivalent of oxone, which resulted in complete substrate consumption. The reactions were not optimized.

The indole ring cleavage product 8 has been previously obtained by superoxide oxidation, ${ }^{85}$ or by metalloporphyrin catalyzed oxidation in $32 \%$ yield ${ }^{86}$ and, more recently, as a product from ozonolysis of $\mathbf{5},{ }^{87}$ whilst 9 has been obtained in a quantitative yield by the periodate oxidation of $6 .{ }^{88} \mathrm{In}$ addition to the indole ring cleavage product 9 , substrate 6 can give rise to a spiro-cyclopentyl-1,2'-indol-3'-one (13, Scheme 4).$^{89}$ On the other hand, the oxidation of 7 readily gave the $N$-acetyl-spiro-cyclopentyl-1,3'-indol-2'-one (10) as observed by Zhang and Foote. ${ }^{81}$ The 2-oxindole ${ }^{90}$ and the isomeric 3-oxindole products are readily distinguished by their different physical and spectroscopic properties where the ${ }^{13} \mathrm{C}$ chemical shifts $\left(\mathrm{CDCl}_{3}\right)$ of the respective carbonyl groups are $184.6^{91}$ and 205.2 ppm. $^{89}$

The contrasting reactivity of the substrates $\mathbf{6}$ and 7 , and the complex product mixture obtained on oxidation of $\mathbf{4}$, reveals that the $\mathrm{N}$-acetyl group modulates the reactivity of the indolic substrates in favor of 2-oxindole product formation. Therefore, the tetrahydro- $\beta$-carboline (THBC) 4 was transformed into the $N^{a}, N^{b}$-diacetyl THBC (14) by heating in a mixture of $\mathrm{Ac}_{2} \mathrm{O} / \mathrm{AcCl}$ (Scheme 5). Treatment of $\mathbf{1 4}$ with DMD, generated in situ, resulted in the formation of a mixture of products. Thin layer chromatography (TLC) analysis revealed the presence of two pairs of products that were subsequently separated and characterized as pairs of diastereoisomeric spiropyrrolidinyl-( $N^{a}$-acetyl)$\left(\mathbf{1 5} \mathbf{a} / \mathbf{b}\right.$, the apolar fraction) and spiropyrrolidinyl- $\left(N^{a}-\mathrm{H}\right)-$ oxindoles (16a/b, the polar fraction). Subsequently,

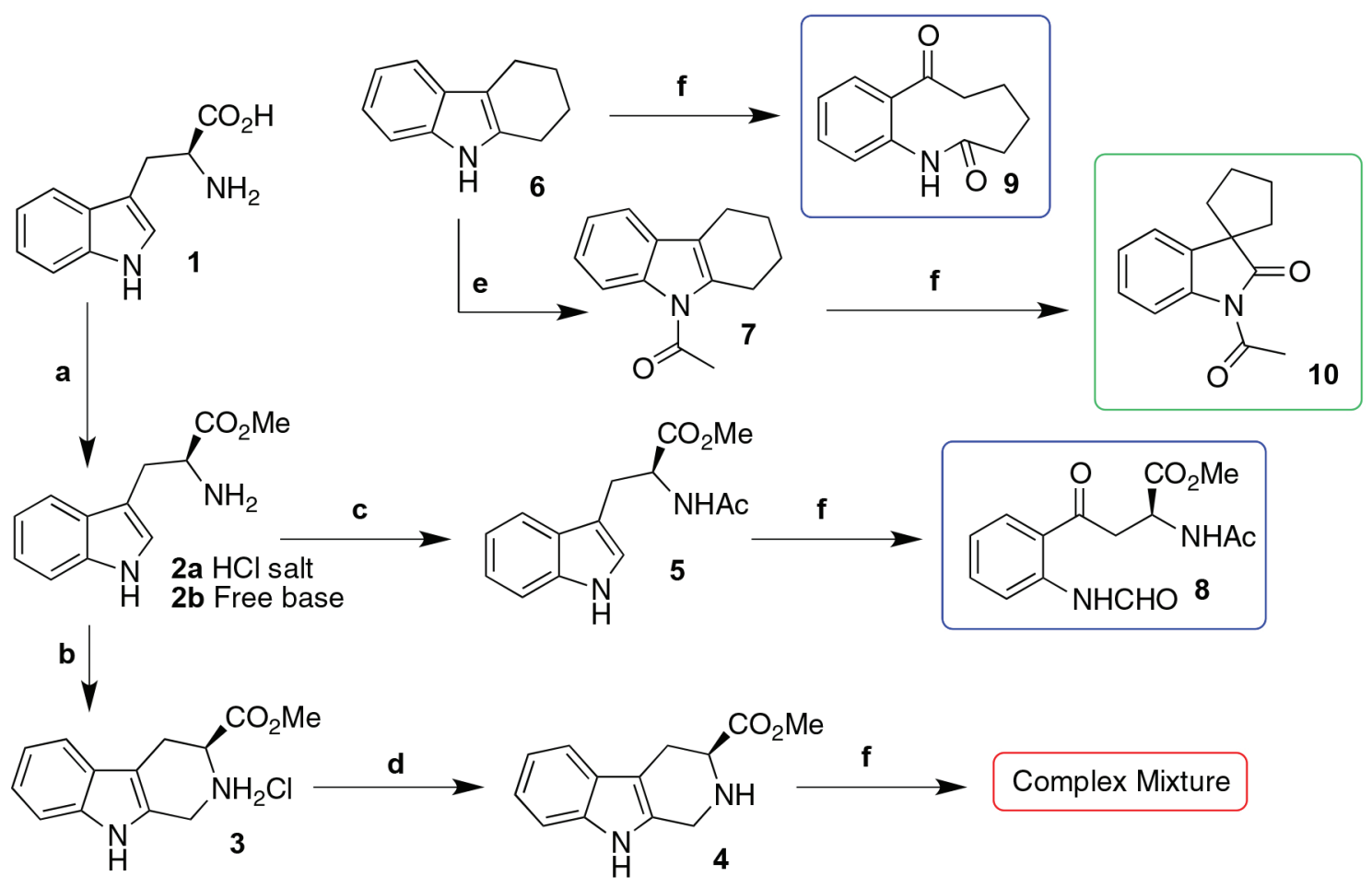

Scheme 3. Synthesis and oxidation of indole derivatives 4-7 with DMD. (a) $\mathrm{MeOH}, \mathrm{SOCl}_{2}$, reflux (quantitative yield (QY)); (b) $\mathrm{CH}_{2} \mathrm{O}, \mathrm{TFA}$, MeOH, reflux (QY); (c) $\mathrm{Ac}_{2} \mathrm{O}, \mathrm{NaOAc}\left(97 \%\right.$ ); (d) aqueous $\mathrm{NH}_{4} \mathrm{OH}$ (97\%); (e) $\mathrm{Ac}_{2} \mathrm{O}, \mathrm{AcCl}, \Delta, 3 \mathrm{~h}\left(83 \%\right.$ ); (f) oxone, $\mathrm{NaHCO}_{3}, \mathrm{H}_{2} \mathrm{O}$, acetone. 


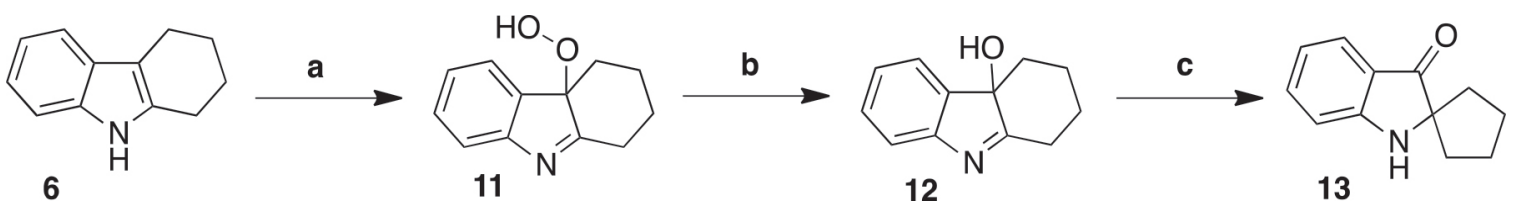

Scheme 4. Synthesis of spiro-cyclopentyl-1,2'-indol-3'-one (13). ${ }^{89}$ (a) Rose Bengal, $\mathrm{O}_{2}, \mathrm{AcOH}$, hv (90\% yield); (b) $10 \%$ aqueous $\mathrm{Na}_{2} \mathrm{SO}_{3}(89 \%$ ); (c) $10 \%$ methanolic $\mathrm{H}_{2} \mathrm{SO}_{4}(98 \%)$.

upon repeating the oxidation reaction, and in order to simplify the characterization and quantification of the diastereoisomers, the product mixture was $N^{a}$-deacetylated by briefly refluxing in $\mathrm{MeOH}$ to which a catalytic quantity of $p$ TSA ( $p$-toluenesulfonic acid) had been added. This resulted in the exclusive formation of the more polar pair of diastereoisomeric $\left(N^{a}-\mathrm{H}\right)$-oxindoles $\mathbf{1 6 a} / \mathbf{b}$ as a 1:1 mixture ( ${ }^{1} \mathrm{H}$ NMR) (Scheme 5).

The mixture was chromatographically separated and the diastereoisomers (the least polar diastereoisomer 16a and the more polar 16b) were individually characterized. 2D NMR experiments were used to assign the ${ }^{1} \mathrm{H}$ and ${ }^{13} \mathrm{C}$ signals. The 2-oxindole substructure was confirmed by: (i) the ${ }^{13} \mathrm{C}$ shift of the oxindole carbonyl groups (177.2 and $180.7 \mathrm{ppm}$ for $\mathbf{1 6 a}$ and $\mathbf{1 6} \mathbf{b}$, respectively); (ii) the heteronuclear multiple bond correlation (HMBC) spectrum revealed that the methylene groups (C8 and $\mathrm{C} 11$, for atom numbering, see Figure 2) of the spiropyrrolidine ring fragment were ${ }^{3} J$ coupled with $\mathrm{C} 3 \mathrm{a}$, the quaternary aromatic carbon bonded to spiro- $\mathrm{C} 3$ of the oxindole fragment, revealing that both methylene groups were bonded to the spiro-C 3 center. The stereochemistry, relative to $L$-tryptophan, was determined by 2D NOESY. In the case of 16a, $\mathrm{H} 4$ of the oxindole nucleus revealed through space dipolar couplings with specific hydrogens (H8b, H11b and H9) of the spiro-pyrrolidine group. The more deshielded hydrogens, H8a and H11a, of the respective methylene groups $(\mathrm{C} 8$ and $\mathrm{C} 11)$ revealed a strong nOe correlation between them, consistent with the respective $\mathrm{C}-\mathrm{H}$ bonds occupying pseudo-axial positions of an envelope conformation of the spiropyrrolidine group, where the spiro- $\mathrm{C} 3$ of the oxindole nucleus is the envelope flap (Figure 2). The distinction between $\mathrm{H} 4$ and $\mathrm{H} 7$ of the oxindole nucleus was ratified by the observation of an nOe correlation between $\mathrm{H} 7$ and the $\mathrm{NH}$ group. Notably, the $N^{b}$-acetyl group of the spiro-pyrrolidinyl group gave rise to two conformers in a 5:1 ratio for 16a and a 3:1 ratio for $\mathbf{1 6} \mathbf{b}$, as determined by integration of the oxindole $\mathrm{NH}$ signals. An nOe interaction of the acetyl methyl group with the hydrogens $\mathrm{H} 11 \mathrm{a}$ and $\mathrm{H} 11 \mathrm{~b}$ of the more deshielded methylene group of the pyrrolidine ring allowed distinction of the conformer structures (Figure 2).

In a similar fashion, a 2D NOESY experiment allowed the stereochemical definition of the diastereoisomer $\mathbf{1 6 b}$ $(S, S)$. The hydrogens $\mathrm{H} 4$ and $\mathrm{H} 7$ were readily defined from their respective nOe dipolar couplings, where $\mathrm{H} 7$ revealed a coupling with the $\mathrm{NH}$ group and $\mathrm{H} 4$ revealed couplings with H8b and H11. In the case of $\mathbf{1 6} \mathbf{b}$, the hydrogens $\mathrm{H} 11 \mathrm{a}$ and $\mathrm{H} 11 \mathrm{~b}$ are magnetically equivalent and gave rise to a singlet ( $\delta 3.92 \mathrm{ppm})$ in the ${ }^{1} \mathrm{H}$ NMR spectrum. Additionally, the hydrogens $\mathrm{H} 8 \mathrm{a}$ and $\mathrm{H} 8 \mathrm{~b}$ revealed nOe correlations with the hydrogens $\mathrm{H} 11$ and the hydrogen H9 with H11 (Figure 2).

With the aim of further exploring the oxidative rearrangement of THBC derivatives, a small group of $N$-AcTHBCs was prepared from $L$-tryptophan methyl ester hydrochloride salt (2a), the structures are given in Figure 3. The synthetic methodology for their preparation is detailed in the Supplementary Information (SI) section.

Initially, trans-21 was oxidized in an analogous fashion to the oxidation of $\mathbf{1 4}$ (Scheme 5). TLC analysis of the reaction revealed four products. However, GC-MS (gas chromatography-mass spectrometry) analysis revealed two pairs of diastereoisomers, the $\mathrm{N}$-acetyloxindoles with molecular ions $m / z, 342\left(60 \%, 4: 1\right.$ ratio) and the $N^{a}-\mathrm{H}$ oxindoles with molecular ions $m / z 300$ (30\%, 2:1 ratio), as well as two unidentified minor products (with molecular ions $m / z 314,10 \%$ total area).

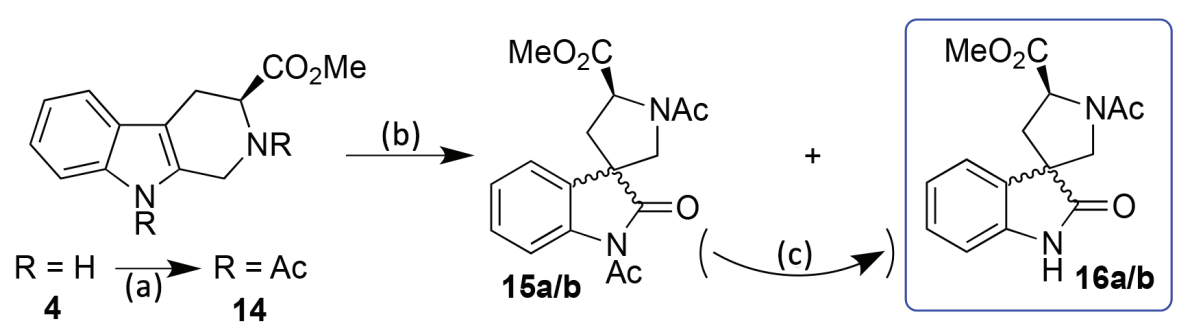

Scheme 5. Synthesis of spiro-pyrrolidinyloxindoles 15 and 16 by DMD oxidation of $N^{a}, N^{b}$-diacetyl-THBC 14. (a) $\mathrm{Ac}{ }_{2} \mathrm{O} / \mathrm{AcCl}, \Delta, 4 \mathrm{~h}$ (71\% yield); (b) oxone, $\mathrm{NaHCO}_{3}, \mathrm{H}_{2} \mathrm{O}$, acetone, 30 min, r.t.; (c) $\mathrm{MeOH}$, cat. $p$ TSA $(10 \mathrm{~mol} \%)(87 \%, 1: 1 \mathbf{1 6 a} / \mathbf{b})$. 


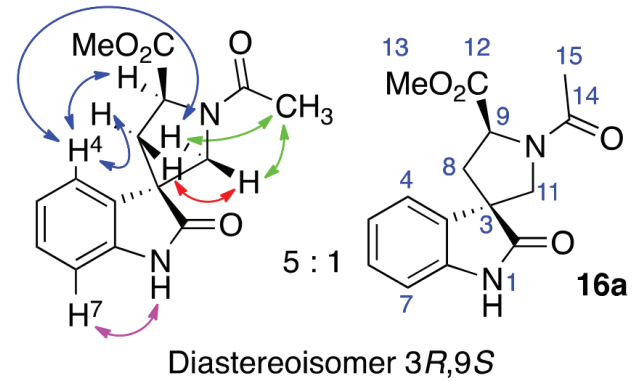

Diastereoisomer 3R,9S

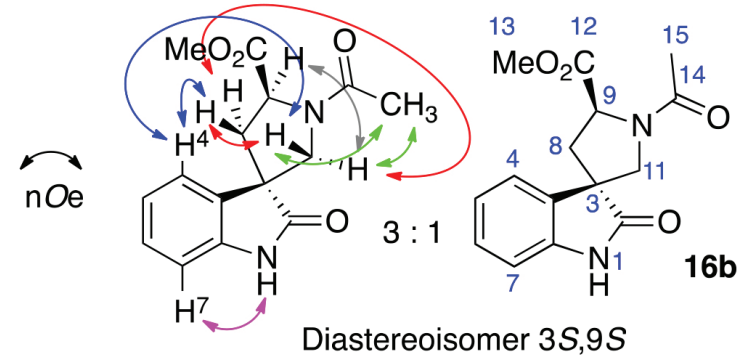

Diastereoisomer 3S,9S
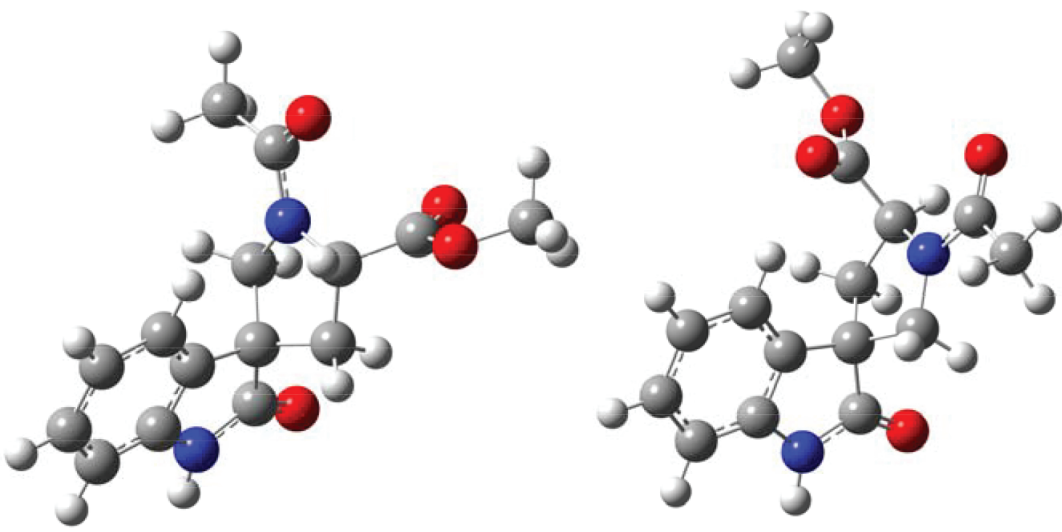

Figure 2. The stereochemistry of the diastereoisomers (16a- $R, S$ on the left and $\mathbf{1 6} \mathbf{b}-S, S$ on the right), relative to $L$-tryptophan, as determined by nOe interactions as well as the respective amide conformer populations for each diastereoisomer and DFT [B3LYP//6-31+G(d,p)] calculated minimum energy conformers of the diastereoisomers.<smiles>CCC1Cc2c(n(-c3ccccc3)c3ccccc23)[C@@H]2CCC(=O)N12</smiles>

$17 \mathrm{R}^{1}=\mathrm{H}$

$21 \mathrm{R}^{1}=\mathrm{AC}$<smiles>[R][C@]12CCC(=O)N1[C@H](C(C)=O)Cc1c2[nH]c2ccccc12</smiles>

$\mathrm{R}^{1} \quad \mathrm{R}^{2}=\mathrm{CO}_{2} \mathrm{Me}$

$18 \mathrm{R}^{1}=\mathrm{H}$

$22 \mathrm{R}^{1}=\mathrm{AC}$<smiles></smiles>

$\mathrm{R}^{1}$

$19 \mathrm{R}^{1}=\mathrm{H}$

$23 R^{1}=A c$

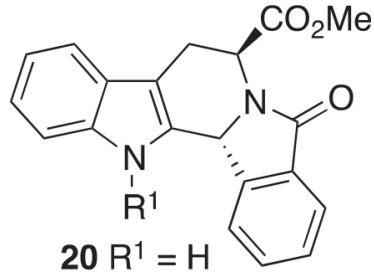

$24 \mathrm{R}^{1}=\mathrm{Ac}$

Figure 3. $N^{a}$-Acetyl tetrahydro- $\beta$-carboline derivatives ( $N^{a}$-AcTHBC's) used to further investigate the oxidative rearrangement.

The principal apolar $N^{a}$-acetyloxindole diastereoisomer (25a) could be partially separated from the product mixture and was recrystallized from EtOAc. The structure was characterized by 2D NMR and the NOESY method was used to determine the relative stereochemistry based upon $L$-tryptophan (Scheme 6 and SI). $N^{a}$-Deacetylation of 25a in $\mathrm{MeOH}$ with a catalytic quantity of $p$ TSA gave the respective apolar $N^{a}$-H oxindole (26a) as determined by comparative TLC with the oxidation product mixture. As expected, determination of the relative stereochemistry of the $N^{a}-\mathrm{H}$ oxindole (26a) revealed this to be the same as the $N^{a}$-acetyl diastereoisomer 25a (Scheme 6). This finding confirmed that epimerization of spiro-C3a, due to a retro-Mannich reaction of the spiro-pyrrolidinyl ring, was not observed to occur under the conditions used for $N^{a}$-deacetylation.

Based upon the observation that the $N^{a}$-H oxindoles $\mathbf{1 6 a} / \mathbf{b}$ (Scheme 5), obtained from the oxidation of the $N^{a}, N^{b}$-diacetyl THBC $\mathbf{1 4}$, could be more readily separated, the oxidized product mixture $(\mathbf{2 5} \mathbf{a} / \mathbf{b} / / \mathbf{2 6} \mathbf{a} / \mathbf{b})$ was $N^{a}$-deacetylated to give $\mathbf{2 6 a} / \mathbf{b}$. However, the chromatographic separation of the $N^{a}$-H diastereoisomers $\mathbf{2 6 a} / \mathbf{b}$ proved to be more challenging. The polar $N^{a}-\mathrm{H}$ diastereoisomer 26b was partially separated from the $N^{a}$-deacetylated mixture. The product was characterized by 2D NMR and the use of NOESY confirmed the inversion of the $\mathrm{C} 3$ spiro center, relative to the $\mathrm{C} 9$ and $\mathrm{C} 11$ asymmetric carbons (Scheme 6 and SI).

In continuation of the investigation, the $N^{a}$-acetyl derivatives (22-24) were oxidized in an analogous fashion and the crude products were subsequently $N^{a}$-deacetylated in methanolic $\mathrm{HCl}$. The crude product was separated into two fractions using a Chromatotron (Harrison Research). The apolar component was generally found to be (by NMR analysis) a mixture of compounds whereas 


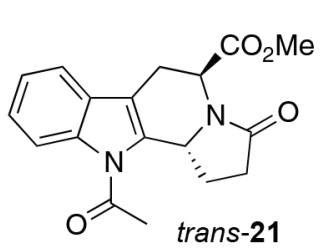

(a)

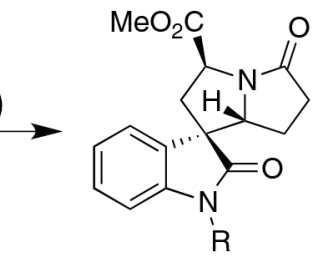

and

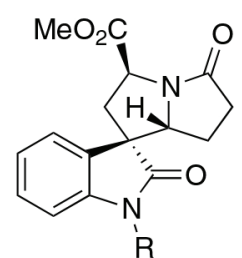

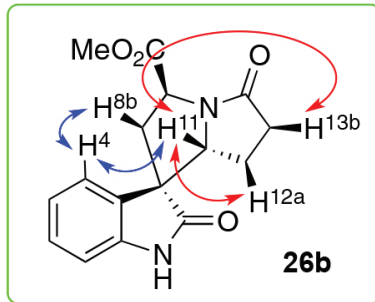

minor polar diastereoisomer

25a/b R = Ac, 60\%, 4:1

26a/b R $=\mathrm{H}, \quad 30 \%, 2: 1$

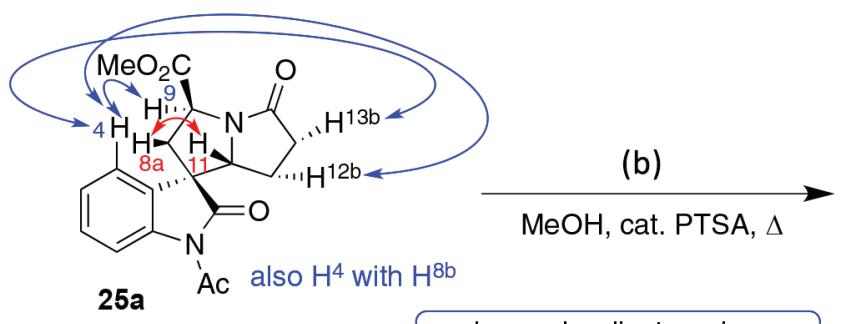

major apolar diastereoisomer

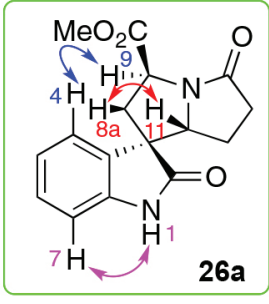

Scheme 6. The oxidative rearrangement of trans-21. The observed nOe interactions for the apolar $N^{a}$-acetyl 25a and $N^{a}$-H $26 \mathbf{a}$ oxindoles as well as the polar $N^{a}$-H oxindole 26b are indicated. (a) Oxone, $\mathrm{NaHCO}_{3}$, acetone/ $\mathrm{H}_{2} \mathrm{O}$; (b) $\mathrm{MeOH}$, cat. $p$ TSA, $\Delta$. Complete atomic numbering of the structures is given with the respective $2 \mathrm{D}$ NMR interpretations in the SI section.

the polar, principal, component was found to be essentially a single diastereoisomer in the case of the products 27 (80\% yield) and 28 (67\% yield), and an estimated 5:1 mixture in the case of $\mathbf{2 9}$ (75\% yield). The structures of the isolated polar products were characterized by
2D NMR and the relative stereochemistry was determined by the use of NOESY experiments (full details are given in the SI section). Scheme 7 summarizes the results and reveals how the substrate structure sterically influences the outcome of the oxidation reaction. Compound 27

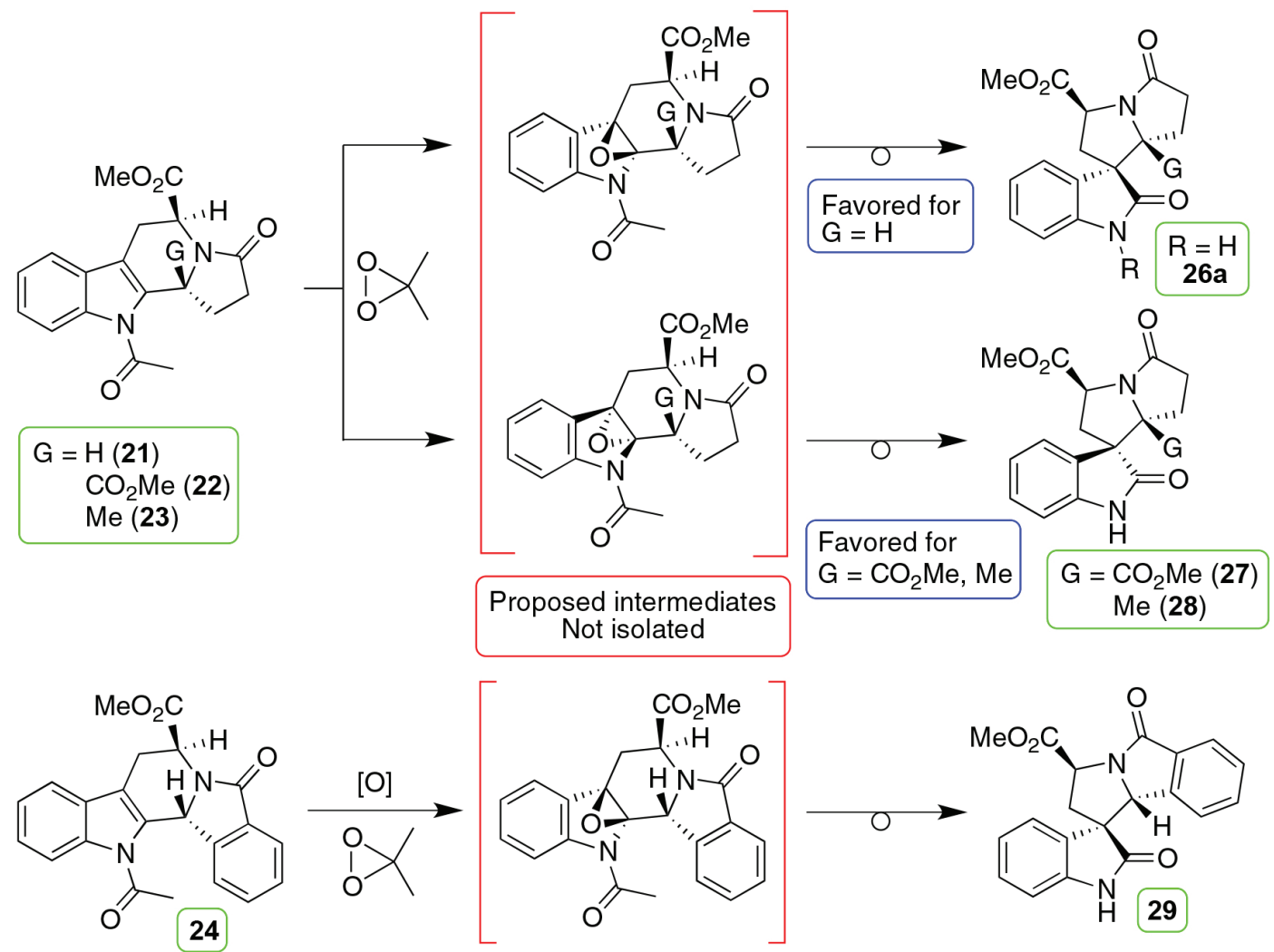

Scheme 7. Summary of the substrate stereochemical influence upon favored product structure in the oxidative rearrangement of the $N^{a}$-acetylpyrrolidinyltetrahydro- $\beta$-carbolines. 
was recently reported by Schendera et al. ${ }^{80}$ They obtained this compound via a 1,2-rearrangement of the 3-hydroxyindolenine. The spectroscopic data and the stereochemical assignments are equivalent. On the other hand, Bathula et al..$^{45}$ obtained what they claimed to be a mixture of diastereoisomers of $\mathbf{2 8}$ when they oxidized $\mathbf{1 9}$ ( $N^{a}$-H substrate for preparation of the $N^{a}$-Ac derivative 23, Figure 3) with dibromodimethylhydantoin (DBDMH) in $\mathrm{AcOH} /$ tetrahydrofuran $(\mathrm{THF}) / \mathrm{H}_{2} \mathrm{O}$.

Based upon the studies of Zhang and Foote ${ }^{81}$ and Adam et al. ${ }^{82}$ the oxidation of the $N^{a}$-acetylindole derivatives is proposed to occur through the formation of an epoxide intermediate that undergoes spontaneous rearrangement, below room temperature, to give the respective spiropyrrolidine-2-oxindole. With this in mind, density functional theory (DFT) calculations were used to investigate the interaction of DMD with $N^{a}$-acetyltetrahydrocarboline (7). Figure 4 portrays the Gibbs free energy $(\Delta \mathrm{G})$ for stationary points and the total electronic energy for the intrinsic reaction coordinate for oxygen atom transfer from DMD to 7. Interestingly, for the gas phase calculation, as DMD approaches the indolic double bond, the oxygen atom transfer for the lowest energy transition state regioselectively occurs at $\mathrm{C} 2$. Following this, as the reaction coordinate relaxes, the indolic $\mathrm{C} 3-\mathrm{C} 2-\mathrm{O}$ angle closes to give the epoxide of 7 as the product. ${ }^{92}$ The inclusion of an implicit solvation model $($ IEFPCM, solvent $=$ water $)$ in the calculation resulted in the smooth transfer of the oxygen atom to both $\mathrm{C} 2$ and $\mathrm{C} 3$ simultaneously, directly yielding the epoxide intermediate.
In a similar fashion, the reaction of DMD with $\mathbf{2 3}$ was calculated. The calculations revealed the differences in the energetics for oxygen atom transfer to the two faces (cis to the methyl and methyl carboxylate substituents or trans with respect to the same substituents) of the indolic double bond. The energetic change $(\Delta \mathrm{H}$ and $\Delta \mathrm{G})$ upon conversion of a van der Waals complex of DMD with $\mathbf{2 3}$ via the transition state for oxygen atom transfer to the van der Waals complex of epoxide and acetone is graphically portrayed in Figure 5 (cis oxygen atom transfer is represented as coordinate $\mathrm{A}$ and trans oxygen atom transfer as coordinate B). The nature of the transition state was observed to be dependent upon the face to which the oxygen atom was being transferred. The sterically congested cis face resulted in oxygen atom transfer to $\mathrm{C} 3$ of the indolic double bond, where the adjacent methylene group is unsubstituted. On the other hand, the less congested trans face resulted in oxygen atom transfer to $\mathrm{C} 2$. The inclusion of an implicit solvation model gave similar results. For both intrinsic reaction coordinates, post transition state relaxation resulted in the formation of the respective epoxides. Notably, $\Delta \Delta \mathrm{G}^{\ddagger}$ for the reaction coordinates was $2.45 \mathrm{kcal} \mathrm{mol}^{-1}$ (equivalent to a diastereoisomeric ratio of 98.5:1.5) and the inclusion of implicit solvation reduced this activation barrier to $1.84 \mathrm{kcal} \mathrm{mol}^{-1}$ (diastereoisomer ratio of 95.7:4.3). The facts that the epoxidation reaction is considerably exothermic (ca. $50 \mathrm{kcal} \mathrm{mol}^{-1}$ ) and that the equilibrium for the epoxidation reaction is completely displaced in favor of the epoxide would imply that the observed diastereoselectivity for the formation of the 2-oxindole products is controlled by formation of the respective epoxides.

\section{Energy variation as a function of the reaction coordinate for epoxidation}

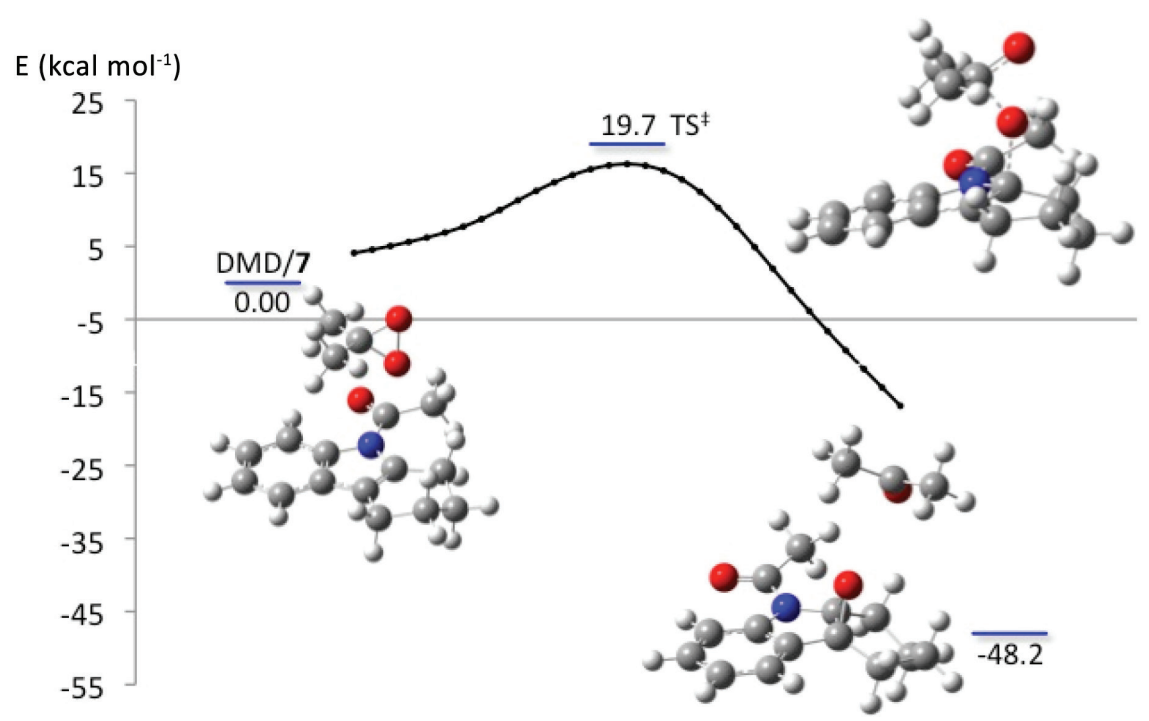

Figure 4. DFT (B3LYP//6-31+G(d)) calculated total electronic energy for the intrinsic reaction coordinate (一) for oxygen atom transfer from DMD to 7 and the Gibbs free energies (and structures) for the stationary points (-) of the reaction coordinate relative to the van der Waals complex DMD/7. 

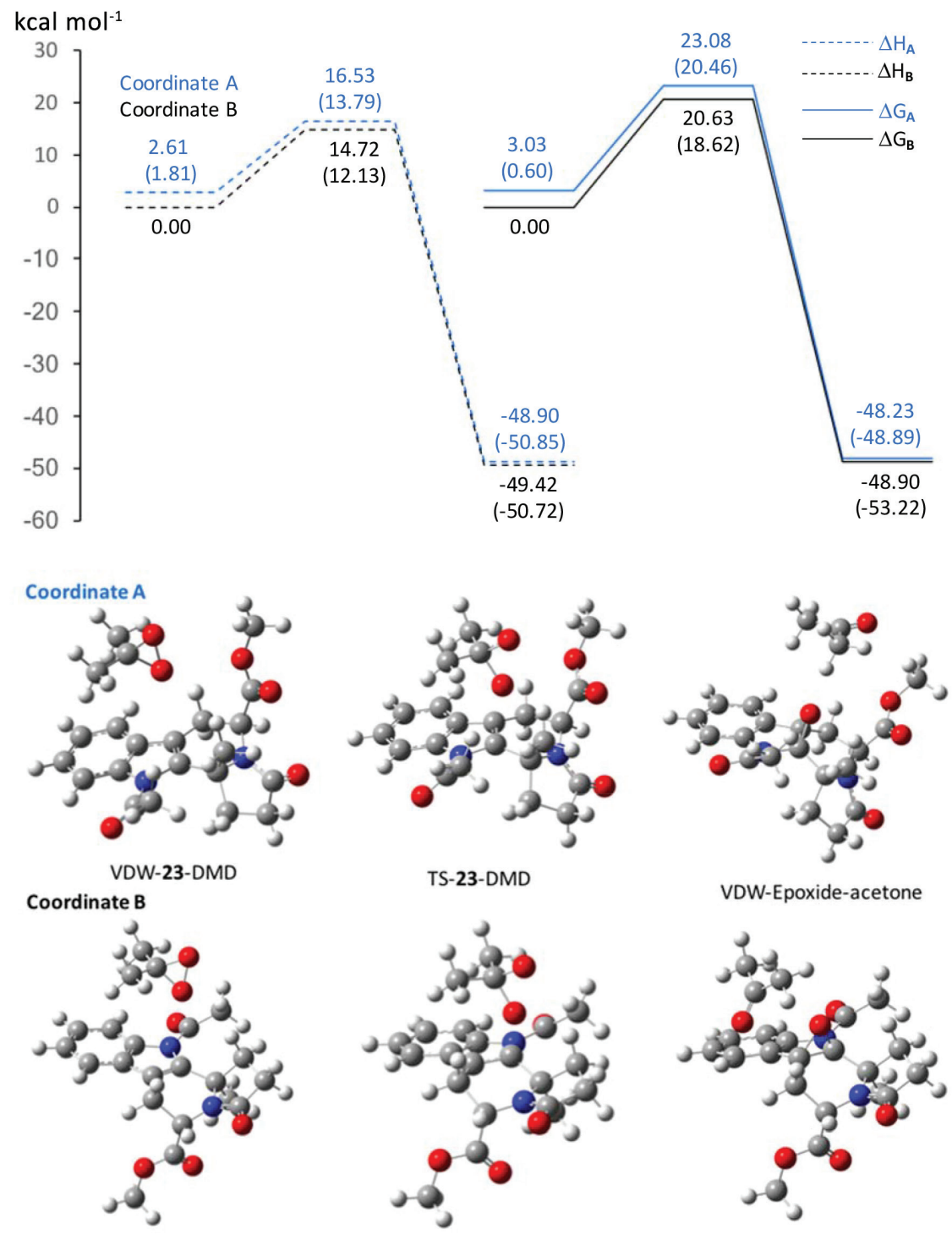

Figure 5. DFT (B3LYP//6-31+G(d)) calculated energies $(\Delta \mathrm{H}$ and $\Delta \mathrm{G}$, values in parenthesis correspond to values calculated with implicit solvation, IEFPCM = water) and structures for stationary points for the epoxidation of $\mathbf{2 3}$ by DMD.

Adam et al.${ }^{82}$ proposed that rearrangement of the indole epoxides occurs by heterolysis of an epoxide $\mathrm{C}-\mathrm{O}$ bond to generate a zwitterionic intermediate. Heterolysis of the $\mathrm{C} 3-\mathrm{O}$ epoxide bond would give rise to a benzylic cation 2-alkoxide zwitterion. A 1,2-alkyl group shift (WagnerMeerwein rearrangement) from $\mathrm{C} 2$ to $\mathrm{C} 3$ would result in the respective 3-alkyl-2-oxindole. A polar protic reaction medium might be expected to stabilize a zwitterionic intermediate, although a concerted epoxide ring opening/ alkyl group migration is not ruled out.

Attempts to locate both transition state for ring opening of the epoxide of $\mathbf{7}$ and minimum energy zwitterionic intermediate, with or without implicit solvation, were unsuccessful (B3LYP/6-31+G(d), IEFPCM = water). However, a transition state for the 1,2-alkyl group migration was located and this was used as a starting point for an intrinsic reaction coordinate calculation (IRC). The IRC calculation endpoints resembled a zwitterionic intermediate and the 2-oxindole product. Optimization of the IRC calculation endpoints resulted in the epoxide of $\mathbf{7}$ and the 2-oxindole $\mathbf{1 0}$ as minimum energy stationary points to either side of the transition state for the 1,2-alkyl group migration. The result is consistent with a concerted ring opening/ring contraction process. The Gibbs activation free energy $\left(\Delta \mathrm{G}^{\ddagger}\right)$ and enthalpy of activation $\left(\Delta \mathrm{H}^{\ddagger}\right)$ for the concerted process are 16.19 and $16.66 \mathrm{kcal} \mathrm{mol}^{-1}$, respectively (Figure 6).

The small activation energies for both epoxidation and rearrangement, combined with the exothermicity of each step, result in a rapid room temperature reaction consistent with the short experimental reaction times and the absence of any observable intermediate. 


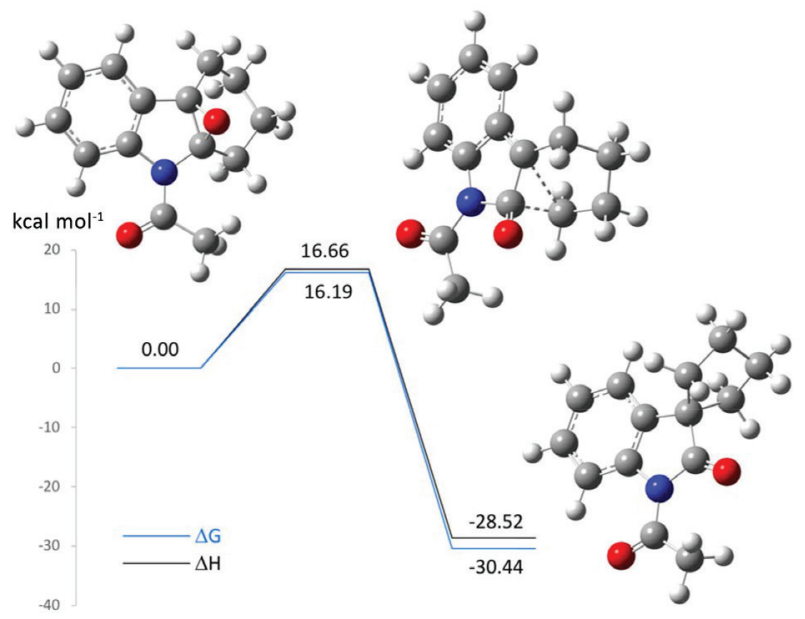

Figure 6. Relative energies (in kcal mol ${ }^{-1}$ ) for stationary points along the reaction coordinate for 2-oxindole $\mathbf{1 0}$ formation from the epoxide of $\mathbf{7}$ (B3LYP//6-31+G(d) IEFPCM = water).

\section{Conclusions}

The oxidation of $\mathrm{N}$-H-indole derivatives (5 and $\mathbf{6}$ ) using DMD generated in situ resulted in the cleavage of the indole ring as exemplified by the products $\mathbf{8}$ and $\mathbf{9}$, whereas the oxidation of the THBC $\mathbf{4}$ gave a complex mixture of products. $\mathrm{N}$-Acetylation of $\mathbf{6}$ and $\mathbf{4}$, to give $\mathbf{7}$ and 14, respectively, followed by oxidation with DMD cleanly resulted in the formation of the oxindoles $\mathbf{1 0}$ and the mixture of spiro-diastereoisomers $N^{a}$-acetyl $15 \mathbf{a} / \mathbf{b}$ and $N^{a}-\mathrm{H} \mathbf{1 6 a} / \mathbf{b}$ in good yields (where 15 was transformed into 16 by $N^{a}$-deacetylation). The oxidative rearrangement was further explored with a small set of $N^{a}$-acetyl pyrrolidinyltetrahydro- $\beta$-carbolines (21-24). DMD oxidation stereoselectively gave the respective spiropyrrolidinyl2-oxindole products without the observation of the formation of isolable hydroxyindolenine intermediates. The oxindole products were spectroscopically characterized and the stereoselectivity of the oxidative rearrangement reaction was qualitatively assessed from ratios of isolated products or by the use of GC-MS and or NMR. The stereochemistry, relative to $L$-tryptophan, of the oxindole products was determined by NOESY. The configuration of the spiro-center of the principal spiro-pyrrolidinyloxindole diastereoisomer was found to be substrate structure dependent.

DFT calculations of the intrinsic reaction coordinate for oxygen atom transfer from DMD to 7 were found to result in the formation of an intermediate epoxide, consistent with experimental results reported by Zhang and Foote. ${ }^{81} \mathrm{~A}$ similar analysis of the epoxidation of $\mathbf{2 3}$ by DMD revealed a face selective epoxidation of the indolic double bond consistent with the experimental isolation of a single 2-oxindole diastereoisomer resulting from the oxidative rearrangement of the diastereoselectively formed epoxide intermediate. A DFT study using implicit solvation for rearrangement of epoxide-7 to give $\mathbf{1 0}$ located a single transition state, characterized as a 1,2-alkyl group migration as a consequence of heterolysis of an epoxide $\mathrm{C}-\mathrm{O}$ bond, and therefore a concerted epoxide ring opening/ ring contraction process to give $\mathbf{1 0}$.

\section{Experimental}

\section{General}

All commercial reagents were used as received. The products of the reactions were purified using a Chromatotron (Harrison Research, silica gel $60 \mathrm{PF}_{254}$ with gypsum). Thin layer chromatography (TLC) was used to monitor the reactions (silica gel 60, $0.2 \mathrm{~mm}$ ). NMR spectra were acquired using Bruker spectrometers (200, 300 and $500 \mathrm{MHz})$. The ${ }^{1} \mathrm{H}$ NMR data are given as the chemical shift $\delta$ (ppm), number of protons, multiplicity and the respective coupling constant(s) $J(\mathrm{~Hz})$. The ${ }^{13} \mathrm{C}$ NMR assignments (where given) are based upon distortionless enhancement by polarization transfer (DEPT) and/or interpretation of 2D spectra. The NMR spectra in $\mathrm{CDCl}_{3}$ are referenced as residual $\mathrm{CHCl}_{3}$ in ${ }^{1} \mathrm{H}$ NMR spectra (7.26 ppm) and as natural abundance ${ }^{13} \mathrm{C}(77.16 \mathrm{ppm})$ unless otherwise indicated. FTIR-ATR (Fourier transform infrared spectroscopy-attenuated total reflectance) spectra were recorded with a Nicolet Magna spectrometer. Highresolution mass spectra (HRMS) were obtained with a QTOF (Micromass) spectrometer. GC-MS analyses were performed with a Shimadzu (QP2010S) gas chromatograph coupled to a mass sensitive detector using an Agilent DB-5 column $(30 \mathrm{~m})$ and helium as carrier gas. Ionization was achieved by electron impact $(70 \mathrm{eV})$. DFT calculations were performed using Gaussian 09C ${ }^{93}$ Procedures for the preparation of the substrates are given in the SI section.

General procedure for the oxidation reactions using dimethyl dioxirane generated in situ

Reactions were generally conducted on a scale of 1 to $10 \mathrm{mmol}$ of the indolic substrate. The following procedure is representative. The substrate $(10 \mathrm{mmol})$ was solubilized in aqueous acetone $(50: 45 \mathrm{~mL})$ to which was added $\mathrm{NaHCO}_{3}$ (3.4 equiv., $34 \mathrm{mmol}$ ). Subsequently, Oxone ${ }^{\circledR}(10 \mathrm{mmol})$ was added in portions during a period of $10 \mathrm{~min}$ at room temperature. $\mathrm{CO}_{2}$ evolution was noted. After 30-60 min, TLC analysis of the reaction revealed the complete consumption of the respective substrate and the formation of the products. The reaction was diluted with aqueous $\mathrm{NaCl}$ solution $(10 \%, 70 \mathrm{~mL})$ and extracted 
with $\mathrm{CH}_{2} \mathrm{Cl}_{2}(4 \times 50 \mathrm{~mL})$. The organic phase was dried with $\mathrm{Na}_{2} \mathrm{SO}_{4}$, filtered and concentrated under reduced pressure to give the crude product as an oil, which solidified with time. The crude products were $N^{a}$-deacetylated (see " $N{ }^{a}$-Deacetylation of the oxidatively rearranged diastereoisomeric mixtures" section) unless otherwise stated. The substrates, methyl $N$-acetyltryptophan ester (5) and tetrahydrocarbazol (6), gave products resulting from oxidative cleavage of the indolic double bond $(\mathbf{8}$ and $\mathbf{9}$, respectively). DMD oxidation of the substrate 7 gave the oxindole 10 in $83-92 \%$ yield, $N^{a}$-deacetylated product was not quantified. ${ }^{81}$ The crude products were purified using a Chromatotron (eluent: hexane:EtOAc, 3:1).

Methyl (S)-2-acetamido-4-(2-formamidophenyl)-4-oxobutanoate $(\mathbf{8})^{85}$

Yield 60\%; ${ }^{1} \mathrm{H}$ NMR $\left(500 \mathrm{MHz}, \mathrm{CDCl}_{3}\right) \delta 11.34(1 \mathrm{H}$, s), $8.71(1 \mathrm{H}, \mathrm{d}, J 8 \mathrm{~Hz}), 8.44(1 \mathrm{H}, \mathrm{s}), 7.91(1 \mathrm{H}, \mathrm{d}, J 8 \mathrm{~Hz})$, $7.57(1 \mathrm{H}, \mathrm{t}, J 8 \mathrm{~Hz}), 7.16(1 \mathrm{H}, \mathrm{t}, J 8 \mathrm{~Hz}), 6.62(1 \mathrm{H}, \mathrm{s}), 3.78-$ $3.70(5 \mathrm{H}, \mathrm{m}), 2.00(3 \mathrm{H}, \mathrm{s}) ;{ }^{13} \mathrm{C} \mathrm{NMR}\left(125 \mathrm{MHz}, \mathrm{CDCl}_{3}\right.$, ref. $77.0 \mathrm{ppm}) \delta 201.8,171.6,170.1,159.9,139.9,135.8$, $130.9,123.2,121.61,120.9,52.7,48.1,41.7,22.9$.

\section{3,4,5,6-Tetrahydro-1 $\mathrm{H}$-benzo[b]azonine-2,7-dione (9) ${ }^{88}$}

Yield 63\%; ${ }^{1} \mathrm{H}$ NMR $\left(200 \mathrm{MHz}, \mathrm{CDCl}_{3}\right) \delta 8.39(1 \mathrm{H}$, s), 7.56-7.35 (3H, m), 7.24-7.20 (1H, m), $2.84(2 \mathrm{H}, \mathrm{bs})$, $2.19(2 \mathrm{H}, \mathrm{bs}), 1.83(4 \mathrm{H}, \mathrm{bs}) ;{ }^{13} \mathrm{C} \mathrm{NMR}\left(50 \mathrm{MHz}, \mathrm{CDCl}_{3}\right.$, ref. $77.0 \mathrm{ppm}) \delta 206.0,176.7,138.9,134.6,132.0,128.5$, $128.3,127.8,41.2,32.2,24.6,24.4$.

$\left(3 R, 3^{\prime} S, 7^{\prime}\right.$ a $R$ ) 3'-Methyl $N^{a}$-acetyl 1,2,2', 3',6', 7'-hexahydro$2,5^{\prime}$-dioxo-spiro[3H-indole-3, 1 '-[1 $\left.H\right]$ pyrrolizine $]$ 3'(5'H)-carboxylate (25a)

From 21 (1.113 g, $3.4 \mathrm{mmol})$, the crude product was obtained as a mixture $(1.121 \mathrm{~g})$ of the $N^{a}$-acetyl $(\mathbf{2 5 a} / \mathbf{b})$ and $N$-H $(\mathbf{2 6 a} / \mathbf{b})$ diastereoisomers. The principal apolar $N^{a}$-acetyl diastereoisomer $\mathbf{2 5 a}$ could be partially separated from the mixture chromatographically on silica using a $\mathrm{CH}_{2} \mathrm{Cl}_{2} /$ EtOAc gradient (0-30\%). Initial fractions gave 25a ( $0.173 \mathrm{~g}$ from $0.550 \mathrm{~g}$ of the crude mixture), which was recrystallized from EtOAc, mp 213-4 ${ }^{\circ} \mathrm{C}$. Posterior fractions were mixtures.

${ }^{1} \mathrm{H}$ NMR $\left(500 \mathrm{MHz}, \mathrm{CDCl}_{3}\right) \delta 8.22(1 \mathrm{H}, \mathrm{d}, J 8.0 \mathrm{~Hz})$, $7.32(1 \mathrm{H}, \mathrm{dd}, J 8.0,7.6 \mathrm{~Hz}), 7.15(1 \mathrm{H}, \mathrm{t}, J 7.6 \mathrm{~Hz}), 6.79$ $(1 \mathrm{H}, \mathrm{d}, J 7.6 \mathrm{~Hz}), 4.73(1 \mathrm{H}, \mathrm{t}, J 8.8 \mathrm{~Hz}), 4.47(1 \mathrm{H}, \mathrm{dd}$, $J$ 8.5, $4.7 \mathrm{~Hz}), 3.75(3 \mathrm{H}, \mathrm{s}), 2.80(1 \mathrm{H}, \mathrm{dd}, J 13.5,8.8 \mathrm{~Hz})$, $2.64(\mathrm{dd}, J 13.5,8.8 \mathrm{~Hz}), 2.61(3 \mathrm{H}, \mathrm{s}), 2.56-2.62(1 \mathrm{H}, \mathrm{m})$, $2.15(1 \mathrm{H}, \mathrm{ddd}, J 17.5,10.8,4.1 \mathrm{~Hz}), 2.07-1.96(1 \mathrm{H}, \mathrm{m})$, 1.24-1.05 (1H, m); ${ }^{13} \mathrm{C}$ NMR (125 MHz, $\left.\mathrm{CDCl}_{3}\right) \delta 176.3$ (CO), $175.6(\mathrm{CO}), 171.0(\mathrm{CO}), 170.6(\mathrm{CO}), 139.9(\mathrm{C})$, $129.6(\mathrm{CH}), 128.0(\mathrm{C}), 126.2(\mathrm{CH}), 122.9(\mathrm{CH}), 117.2$
$(\mathrm{CH}), 70.0(\mathrm{CH}), 56.8(\mathrm{C}), 54.9(\mathrm{CH}), 53.0\left(\mathrm{CH}_{3}\right), 43.2$ $\left(\mathrm{CH}_{2}\right), 33.1\left(\mathrm{CH}_{2}\right), 26.9\left(\mathrm{CH}_{3}\right), 18.9\left(\mathrm{CH}_{2}\right)$. Mass spectrum (electrospray ionization, $\mathrm{ESI}(+)$ ) $m / z \mathrm{C}_{18} \mathrm{H}_{18} \mathrm{~N}_{2} \mathrm{O}_{5}[\mathrm{M}+\mathrm{Na}]^{+}$ calcd. 365.1108, obs. 365.1099.

$N^{a}$-Deacetylation of the oxidatively rearranged diastereoisomeric mixtures

The $N^{a}$-acetyl 1,2,3,4-tetrahydro- $\beta$-carbolines ( 14 and 21-24) gave mixtures of $N^{a}$-H and $N^{a}$-acetyl diastereoisomeric 2-oxindole products. Therefore, the product mixture was hydrolyzed to give the deacetylated $N^{a}$-H oxindole diastereoisomers. The crude diastereoisomeric mixture from the oxidative rearrangement reaction was heated for a period of $40 \mathrm{~min}$ in $\mathrm{MeOH}(10 \mathrm{~mL})$ to which a few drops of $\mathrm{AcCl}$ (or $10 \mathrm{~mol} \%$ of $p \mathrm{TSA}$ in relation to the substrate) had been added. TLC confirmed the complete transformation of the $N$-acetyloxindole diastereoisomers into the deacetylated $\mathrm{N}$-H oxindole diastereoisomers. The reaction mixture was concentrated by evaporating the volatiles under reduced pressure, and the crude products were partitioned between aqueous $10 \% \mathrm{NaHCO}_{3}$ and EtOAc. The organic phase was separated, dried over $\mathrm{Na}_{2} \mathrm{SO}_{4}$, filtered and evaporated under reduced pressure. The crude products were purified using the Chromatotron (eluent: hexane:EtOAc, 3:1 unless otherwise indicated).

Methyl (5'S)-1'-acetyl-2-oxo-1H-spiro[indole3,3'-pyrrolidine]-5'-carboxylate (16a/b)

Yield 87\% (16a:16b, 1:1).

Methyl (3R,5'S)-1'-acetyl-2-oxo-1H-spiro[indole3,3'-pyrrolidine]-5'-carboxylate (16a)

IR (ATR) $v / \mathrm{cm}^{-1} 3292,3093,2882,1744,1717,1619$, 1487, 1472, 1442, 1366, 1267, 1200, 1177, 1108, 1036, $887,867,779,758 ;{ }^{1} \mathrm{H} \mathrm{NMR}\left(200 \mathrm{MHz}, \mathrm{CDCl}_{3}\right) \delta 9.21(1 \mathrm{H}$, s), $7.27(1 \mathrm{H}, \mathrm{td}, J 1.5,7.6 \mathrm{~Hz}), 7.15-7.05(2 \mathrm{H}, \mathrm{m}), 6.99(1 \mathrm{H}$, d, $J 7.8 \mathrm{~Hz}), 4.86(1 \mathrm{H}, \mathrm{t}, J 9.5 \mathrm{~Hz}), 4.05(1 \mathrm{H}, \mathrm{d}, J 10.1 \mathrm{~Hz})$, $3.77(3 \mathrm{H}, \mathrm{s}), 3.67\left(1 \mathrm{H}, \mathrm{dd},{ }^{4} J_{\mathrm{w}} 1.5,10.1 \mathrm{~Hz}\right), 2.56(1 \mathrm{H}, \mathrm{dd}$, $J$ 9.5, $12.8 \mathrm{~Hz}), 2.40\left(1 \mathrm{H}, \mathrm{ddd},{ }^{4} J_{\mathrm{W}} 1.5,8.1,12.8 \mathrm{~Hz}\right), 2.10$ $(3 \mathrm{H}, \mathrm{s}) ;{ }^{13} \mathrm{C}$ NMR $\left(50 \mathrm{MHz}, \mathrm{CDCl}_{3}\right) \delta 177.3(\mathrm{CO}), 171.7$ (CO), 169.7 (CO), $140.2(\mathrm{C}), 132.9(\mathrm{C}), 129.0(\mathrm{CH}), 123.4$ $(\mathrm{CH}), 122.3(\mathrm{CH}), 110.7(\mathrm{CH}), 58.5(\mathrm{CH}), 56.4\left(\mathrm{CH}_{2}\right), 53.4$ (C), $52.6\left(\mathrm{OCH}_{3}\right), 39.2\left(\mathrm{CH}_{2}\right), 22.4\left(\mathrm{CH}_{3}\right)$. Mass spectrum $(\mathrm{ESI}(+)) \mathrm{m} / 2 \mathrm{C}_{15} \mathrm{H}_{16} \mathrm{~N}_{2} \mathrm{O}_{4}[\mathrm{M}+\mathrm{Na}]^{+}$calcd. 311.1003, obs. 311.0993; [2M + Na $]^{+}$calcd. 599.2113, obs. 599.2103.

Methyl (3S, 5' $S$ )-1'-acetyl-2-oxo-1 $H$-spiro[indole3,3'-pyrrolidine]-5'-carboxylate (16b)

IR (ATR) $v / \mathrm{cm}^{-1} 3230,3068,3021,2950,2867,1763$, 1723, 1621, 1467, 1452, 1439, 1404, 1336, 1261, 1189, 
1176, 1150, 1104, 768, 759, 708; 'H NMR (200 MHz, $\left.\mathrm{CDCl}_{3}\right) \delta 9.29(1 \mathrm{H}, \mathrm{s}), 7.30(1 \mathrm{H}, \mathrm{dd}, J 1.1,7.7 \mathrm{~Hz}), 7.25$ $(1 \mathrm{H}, \mathrm{td}, J 1.1,7.7 \mathrm{~Hz}), 7.05(1 \mathrm{H}, \mathrm{td}, J 1.1,7.7 \mathrm{~Hz}), 6.95$ $(1 \mathrm{H}, \mathrm{d}, J 7.7 \mathrm{~Hz}), 4.93(1 \mathrm{H}, \mathrm{t}, J 8.3 \mathrm{~Hz}), 3.92(2 \mathrm{H}, \mathrm{s}), 3.77$ $(3 \mathrm{H}, \mathrm{s}), 2.66(1 \mathrm{H}, \mathrm{dd}, J 8.3,13.3 \mathrm{~Hz}), 2.30(1 \mathrm{H}, \mathrm{dd}, J 8.3$, $13.3 \mathrm{~Hz}$ ), $2.10(3 \mathrm{H}, \mathrm{s}) ;{ }^{13} \mathrm{C} \mathrm{NMR}\left(50 \mathrm{MHz}, \mathrm{CDCl}_{3}\right) \delta 180.9$ (CO), $172.6(\mathrm{CO}), 169.5(\mathrm{CO}), 141.2(\mathrm{C}), 129.2(\mathrm{CH})$, $129.1(\mathrm{C}), 123.3(\mathrm{CH}), 123.1(\mathrm{CH}), 110.5(\mathrm{CH}), 58.9(\mathrm{CH})$, $55.7(\mathrm{CH}), 52.9(\mathrm{C}), 52.5\left(\mathrm{OCH}_{3}\right), 39.0\left(\mathrm{CH}_{2}\right), 22.4\left(\mathrm{CH}_{3}\right)$. Mass spectrum $(\mathrm{ESI}(+)) m / z \mathrm{C}_{15} \mathrm{H}_{16} \mathrm{~N}_{2} \mathrm{O}_{4}[\mathrm{M}+\mathrm{Na}]^{+}$calcd. 311.1003, obs. 311.0999; [2M + Na $]^{+}$calcd. 599.2113, obs. 599.2113 .

(3'S,7'aR) 3'-Methyl 1,2,2',3',6',7'-hexahydro-2,5'-dioxospiro[3H-indole-3,1'-[1 $H]$ pyrrolizine]-3' $(5 ' H)$-carboxylate $(26 \mathrm{a} / \mathrm{b})$

A part of the crude product mixture of $25 \mathbf{a} / \mathbf{b}$ and $26 \mathbf{a} / \mathbf{b}$ $(0.550 \mathrm{~g})$ was hydrolyzed to give a mixture of $\mathbf{2 6} \mathbf{a} / \mathbf{b}$. This was chromatographically separated using $\mathrm{CH}_{2} \mathrm{Cl}_{2}$ :EtOAc $(9: 1 \mathrm{v} / \mathrm{v})$ to give the apolar $26 \mathbf{a}(347 \mathrm{mg})$ and the polar 26b (131 mg).

Apolar (3R,3'S,7'aR) 3'-methyl 1,2,2',3',6',7'-hexahydro2,5 '-dioxo-spiro[3H-indole-3,1'-[1 $\mathrm{H}$ ]pyrrolizine]3'(5'H)-carboxylate (26a)

${ }^{1} \mathrm{H}$ NMR $\left(500 \mathrm{MHz}, \mathrm{CDCl}_{3}\right) \delta 9.04(1 \mathrm{H}, \mathrm{s}, \mathrm{NH}), 7.28$ $(1 \mathrm{H}, \mathrm{td}, J 7.7,1.1 \mathrm{~Hz}), 7.04(1 \mathrm{H}, \mathrm{td}, J$ 7.6, $1.0 \mathrm{~Hz}), 6.99$ $(1 \mathrm{H}, \mathrm{d}, J 7.8 \mathrm{~Hz}), 6.86(1 \mathrm{H}, \mathrm{dd}, J 7.6,1.1 \mathrm{~Hz}), 4.80(1 \mathrm{H}$, t, $J 8.8 \mathrm{~Hz}), 4.53(1 \mathrm{H}, \mathrm{dd}, J 8.5,4.7 \mathrm{~Hz}), 2.82(1 \mathrm{H}, \mathrm{dd}$, $J 13.3,9.1 \mathrm{~Hz}), 2.73-2.61(\mathrm{~m}, 2 \mathrm{H}), 2.25$ (1H, ddd, $J 17.6$, 11.0, 4.2 Hz), 2.08 (1H, dddt, $J$ 17.1, 8.7, 7.0, $4.4 \mathrm{~Hz}$ ), $1.26(1 \mathrm{H}$, dddd, $J 13.7,11.0,7.6,4.7 \mathrm{~Hz}) ;{ }^{13} \mathrm{C}$ NMR $\left(125 \mathrm{MHz}, \mathrm{CDCl}_{3}\right) \delta 177.3(\mathrm{CO}), 176.0(\mathrm{CO}), 171.3$ (CO), $140.8(\mathrm{C}), 129.3(\mathrm{C}), 129.2(\mathrm{CH}), 123.5(\mathrm{CH}), 123.5$ $(\mathrm{CH}), 110.7(\mathrm{CH}), 69.1(\mathrm{CH}), 56.9(\mathrm{C}), 54.9(\mathrm{CH}), 52.9$ $\left(\mathrm{CH}_{3}\right), 41.9\left(\mathrm{CH}_{2}\right), 33.1\left(\mathrm{CH}_{2}\right), 18.9\left(\mathrm{CH}_{2}\right)$. Mass spectrum $(\mathrm{ESI}(+)) \mathrm{m} / z \mathrm{C}_{16} \mathrm{H}_{16} \mathrm{~N}_{2} \mathrm{O}_{4}[\mathrm{M}+\mathrm{Na}]^{+}$calcd. 323.1002, obs. 323.0989 .

Polar (3S,3'S,7'aR) 3'-methyl 1,2,2',3',6',7'-hexahydro2,5 '-dioxo-spiro[3H-indole-3, 1 '-[1 $H$ ] pyrrolizine]$3^{\prime}\left(5^{\prime} H\right)$-carboxylate $(\mathbf{2 6 b})$

IR (ATR) v / $\mathrm{cm}^{-1} 3209,3041,3000,2944,1703,1669$, 1619, 1472, 1466, 1432, 1288, 1234, 1183, 756; ${ }^{1} \mathrm{H}$ NMR $\left(500 \mathrm{MHz}, \mathrm{CDCl}_{3}\right) \delta 9.12(1 \mathrm{H}, \mathrm{s}), 7.28-7.24(1 \mathrm{H}, \mathrm{m}), 7.22$ $(1 \mathrm{H}, \mathrm{dd}, J 7.5,1.1 \mathrm{~Hz}), 7.07(1 \mathrm{H}, \mathrm{td}, J$ 7.6, $0.9 \mathrm{~Hz}), 6.98$ $(1 \mathrm{H}, \mathrm{d}, J 7.8 \mathrm{~Hz}), 4.92(1 \mathrm{H}, \mathrm{t}, J 8.4 \mathrm{~Hz}), 4.45(1 \mathrm{H}, \mathrm{dd}, J 8.7$, $4.3 \mathrm{~Hz}), 3.80(3 \mathrm{H}, \mathrm{s}), 2.84(1 \mathrm{H}, \mathrm{dd}, J 13.7,8.5 \mathrm{~Hz}), 2.70-$ $2.60(1 \mathrm{H}, \mathrm{m}), 2.58-2.49(2 \mathrm{H}, \mathrm{m}), 2.19-2.08(1 \mathrm{H}, \mathrm{m}), 1.80-$ $1.68(1 \mathrm{H}, \mathrm{m}) ;{ }^{13} \mathrm{C}$ NMR $\left(125 \mathrm{MHz}, \mathrm{CDCl}_{3}\right) \delta 180.1(\mathrm{CO})$, $177.4(\mathrm{CO}), 172.4(\mathrm{CO}), 141.4(\mathrm{C}), 129.3(\mathrm{CH}), 127.2$
(C), $123.1(\mathrm{CH}), 122.9(\mathrm{CH}), 110.7(\mathrm{CH}), 69.1(\mathrm{CH}), 55.8$ (C), $55.7(\mathrm{CH}), 52.8\left(\mathrm{CH}_{3}\right), 41.4\left(\mathrm{CH}_{2}\right), 32.6\left(\mathrm{CH}_{2}\right), 19.6$ $\left(\mathrm{CH}_{2}\right)$. Mass spectrum $(\mathrm{ESI}(+)) \mathrm{m} / 2 \mathrm{C}_{16} \mathrm{H}_{16} \mathrm{~N}_{2} \mathrm{O}_{4}[\mathrm{M}+\mathrm{Na}]^{+}$ calcd. 323.1002, obs. 323.0997.

(3S,3'S,7'aR) 3',7'a-Dimethyl 1,2,2',3',6',7'-hexahydro2,5'-dioxo-spiro[3H-indole-3, 1 '-[1 $H$ ] pyrrolizine]3',7'a(5'H)-dicarboxylate (27)

A single diastereoisomer was isolated in $80 \%$ yield. IR (ATR) v / $\mathrm{cm}^{-1}$ 3244, 2956, 2926, 2854, 1721, 1713, 1699, 1620, 1472, 1438, 1333, 1232, 1192, 1078, 756; ${ }^{1} \mathrm{H}$ NMR $\left(500 \mathrm{MHz}, \mathrm{CDCl}_{3}\right) \delta 9.23(1 \mathrm{H}, \mathrm{s}), 7.24(1 \mathrm{H}, \mathrm{td}$, $J$ 7.6, $1.3 \mathrm{~Hz}), 7.05-6.97(2 \mathrm{H}, \mathrm{m}), 6.86(1 \mathrm{H}, \mathrm{d}, J 7.4 \mathrm{~Hz})$, $5.01(1 \mathrm{H}, \mathrm{t}, J 8.4 \mathrm{~Hz}), 3.80(3 \mathrm{H}, \mathrm{s}), 3.75(3 \mathrm{H}, \mathrm{s}), 3.01(1 \mathrm{H}$, $\mathrm{dd}, J 7.9,13.8 \mathrm{~Hz}), 2.71(1 \mathrm{H}, \mathrm{dd}, J 8.9,13.8 \mathrm{~Hz}), 2.75-2.60$ $(2 \mathrm{H}, \mathrm{m}), 2.52-2.47(1 \mathrm{H}, \mathrm{m}), 2.06-2.02(1 \mathrm{H}, \mathrm{m}) ;{ }^{13} \mathrm{C} \mathrm{NMR}$ $\left(125 \mathrm{MHz}, \mathrm{CDCl}_{3}\right) \delta 179.4(\mathrm{CO}), 177.6(\mathrm{CO}), 171.6(\mathrm{CO})$, $171.0(\mathrm{CO}), 141.7(\mathrm{C}), 129.8(\mathrm{CH}), 124.6(\mathrm{C}), 123.8(\mathrm{CH})$, $122.8(\mathrm{CH}), 110.9(\mathrm{CH}), 78.1(\mathrm{C}), 58.9(\mathrm{C}), 56.9(\mathrm{CH}), 52.7$ $\left(\mathrm{CH}_{3}\right), 52.5\left(\mathrm{CH}_{3}\right), 38.6\left(\mathrm{CH}_{2}\right), 32.4\left(\mathrm{CH}_{2}\right), 23.7\left(\mathrm{CH}_{2}\right)$. Mass spectrum (ESI(+)) $m / z \mathrm{C}_{18} \mathrm{H}_{18} \mathrm{~N}_{2} \mathrm{O}_{6}[\mathrm{M}+\mathrm{Na}]^{+}$calcd. 381.1062, obs. 381.1057.

(3S, 3' $S, 7^{\prime}$ a $R$ ) 3'-Methyl 1,2,2', 3', 6', 7'-hexahydro7'a-methyl-2,5'-dioxo-spiro[3H-indole-3,1'-[1 $H$ ]pyrrolizine]3'(5'H)-carboxylate (28)

A single diastereoisomer was isolated in $67 \%$ yield. IR (ATR) $v / \mathrm{cm}^{-1} 3250,2983,2958,2926,1709,1680,1666$, 1619, 1472, 1435, 1334, 1241, 1178, 1110, 754; ${ }^{1} \mathrm{H}$ NMR $\left(200 \mathrm{MHz}, \mathrm{CDCl}_{3}\right) \delta 8.69(1 \mathrm{H}, \mathrm{s}), 7.35-7.15(2 \mathrm{H}, \mathrm{m})$, $7.04(1 \mathrm{H}, \mathrm{t}, J 7.6 \mathrm{~Hz}), 6.94(1 \mathrm{H}, \mathrm{d}, J 7.6 \mathrm{~Hz}), 4.88(1 \mathrm{H}, \mathrm{t}$, $J 8.7 \mathrm{~Hz}), 3.79(3 \mathrm{H}, \mathrm{s}), 2.80-2.65(3 \mathrm{H}, \mathrm{m}), 2.47(1 \mathrm{H}, \mathrm{ddd}$, $J$ 3.7, 11.1, $17.5 \mathrm{~Hz}), 2.10-1.90(1 \mathrm{H}, \mathrm{m}), 1.85-1.60(1 \mathrm{H}$, $\mathrm{m}), 1.58(3 \mathrm{H}, \mathrm{s}) ;{ }^{13} \mathrm{C} \mathrm{NMR}\left(50 \mathrm{MHz}, \mathrm{CDCl}_{3}\right) \delta 180.6(\mathrm{CO})$, $177.0(\mathrm{CO}), 172.7(\mathrm{CO}), 141.8(\mathrm{C}), 129.3(\mathrm{CH}), 126.4$ (C), $125.7(\mathrm{CH}), 122.6(\mathrm{CH}), 110.5(\mathrm{CH}), 72.6(\mathrm{C}), 59.2$ (C), $54.6(\mathrm{CH}), 52.7\left(\mathrm{OCH}_{3}\right), 39.6\left(\mathrm{CH}_{2}\right), 33.0\left(\mathrm{CH}_{2}\right), 29.2$ $\left(\mathrm{CH}_{2}\right), 26.5\left(\mathrm{CH}_{3}\right)$. Mass spectrum (ESI $\left.(+)\right) m / z \mathrm{C}_{17} \mathrm{H}_{18} \mathrm{~N}_{2} \mathrm{O}_{4}$ $[\mathrm{M}+\mathrm{Na}]^{+}$calcd. 337.1211 , obs. $337.1158 ;[2 \mathrm{M}+\mathrm{Na}]^{+}$ calcd. 651.2525, obs. 651.2425.

(3R,3'S,7'aR) 3'-Methyl 1,2,2',3'-tetrahydro-2,5'-dioxospiro[3H-indole-3, 1'-benzo[6', 7'][1 $1 \mathrm{H}$ ]pyrrolizine]$3^{\prime}\left(5^{\prime} H\right)$-carboxylate (29)

Yield 75\% (approximately 5:1 ratio of diastereoisomers); IR (ATR) $v / \mathrm{cm}^{-1} 3263,2953,2923,2848,1744,1724,1681$, 1472, 1370, 1307, 1174, 757, 723. Data for the principal isomer: ${ }^{1} \mathrm{H} \mathrm{NMR}\left(500 \mathrm{MHz}, \mathrm{CDCl}_{3}\right) \delta 8.63(1 \mathrm{H}, \mathrm{s}), 7.73(1 \mathrm{H}$, $\mathrm{d}, J 7.4 \mathrm{~Hz}), 7.31(1 \mathrm{H}, \mathrm{t}, J 7.4 \mathrm{~Hz}), 7.28(1 \mathrm{H}, \mathrm{d}, J 7.4 \mathrm{~Hz})$, $7.03(1 \mathrm{H}, \mathrm{d}, J 7.4 \mathrm{~Hz}), 7.02(1 \mathrm{H}, \mathrm{t}, J 7.6 \mathrm{~Hz}), 6.82(1 \mathrm{H}, \mathrm{d}$, $J 7.6 \mathrm{~Hz}), 6.69(1 \mathrm{H}, \mathrm{t}, J 7.6 \mathrm{~Hz}), 6.48(1 \mathrm{H}, \mathrm{d}, J 7.6 \mathrm{~Hz}), 5.42$ 
$(1 \mathrm{H}, \mathrm{s}), 4.98(1 \mathrm{H}, \mathrm{dd}, J 8.5,9.5 \mathrm{~Hz}), 3.86(3 \mathrm{H}, \mathrm{s}), 3.19(1 \mathrm{H}$, dd, $J 9.5,13.3 \mathrm{~Hz}), 2.90(1 \mathrm{H}, \mathrm{dd}, J 8.5,13.3 \mathrm{~Hz}) ;{ }^{13} \mathrm{C} \mathrm{NMR}$ $\left(125 \mathrm{MHz}, \mathrm{CDCl}_{3}\right) \delta 177.0(\mathrm{CO}), 171.4(\mathrm{CO}), 170.9(\mathrm{CO})$, $141.8(\mathrm{C}), 139.7(\mathrm{C}), 133.6(\mathrm{C}), 132.5(\mathrm{CH}), 129.2(\mathrm{CH})$, $128.8(\mathrm{CH}), 128.6(\mathrm{C}), 124.2(\mathrm{CH}), 123.3(\mathrm{CH}), 123.2(\mathrm{CH})$, $122.1(\mathrm{CH}), 110.3(\mathrm{CH}), 71.0(\mathrm{CH}), 55.4(\mathrm{C}), 55.0(\mathrm{CH}), 53.0$ $\left(\mathrm{OCH}_{3}\right), 43.9\left(\mathrm{CH}_{2}\right)$. Mass spectrum $(\mathrm{ESI}(+)) m / z \mathrm{C}_{20} \mathrm{H}_{16} \mathrm{~N}_{2} \mathrm{O}_{4}$ $[\mathrm{M}+\mathrm{Na}]^{+}$calcd. 371.1007, obs. 371.1002. $[2 \mathrm{M}+\mathrm{Na}]^{+}$calcd. 719.2117, obs. 719.2112 .

\section{Supplementary Information}

Supplementary data are available free of charge at http://jbcs.sbq.org.br as PDF file.

\section{Acknowledgments}

The authors thank FAPERJ, CAPES and CNPq for financial support and the mass spectrometry facilities at IPPN and CEMBIO (UFRJ) for the HRMS.

\section{References}

1. Galliford, C. V.; Scheidt, K. A.; Angew. Chem., Int. Ed. 2007, 46,8748 .

2. Yu, B.; Yu, D. Q.; Liu, H. M.; Eur. J. Med. Chem. 2015, 97, 673.

3. Lin, H.; Danishefsky, S. J.; Angew. Chem., Int. Ed. 2003, 42, 36.

4. Williams, R. M.; Cox, R. J.; Acc. Chem. Res. 2003, 36, 127.

5. Jossang, A.; Jossang, P.; Hadi, H. A.; Sevenet, T.; Bodo, B.; J. Org. Chem. 1991, 56, 6527.

6. Anderton, N.; Cockrum, P. A.; Colegate, S. M.; Edgar, J. A.; Flower, K.; Vit, I.; Willing, R. I.; Phytochemistry 1998, 48, 437.

7. Pellegrini, C.; Weber, M.; Borschberg, H.-J.; Helv. Chim. Acta 1996, 79, 151.

8. Kang, T.-H.; Murakami, Y.; Takayama, H.; Kitajima, M.; Aimi, N.; Watanabe, H.; Matsumoto, K.; Life Sci. 2004, 76, 331; Kang, T.-H.; Murakami, Y.; Matsumoto, K.; Takayama, H.; Kitajima, M.; Aimi, N.; Watanabe, H.; Eur. J. Pharmacol. 2002, 455, 27; Trager, W. F.; Lee, C. M.; Phillipson, J. D.; Haddock, R. E.; Dwuma-Badu, D.; Beckett, A. H.; Tetrahedron 1968, 24, 523.

9. Yeoh, G. B.; Chan, K. C.; Morsingh, F.; Tetrahedron Lett. 1966, 931; Chan, K. C.; Morsingh, F.; Yeoh, G. B.; J. Chem. Soc. C 1966, 2245; Bacher, N.; Tiefenthaler, M.; Sturm, S.; Stuppner, H.; Ausserlechner, M. J.; Kofler, R.; Konwalinka, G.; Br. J. Haematol. 2006, 132, 615; Paniagua-Perez, R.; Madrigal-Bujaidar, E.; Molina-Jasso, D.; Reyes-Cadena, S.; Alvarez-Gonzalez, I.; Sanchez-Chapul, L.; Perez-Gallaga, J.; Basic Clin. Pharmacol. Toxicol. 2009, 104, 222.

10. Sakai, S.; Aimi, N.; Yamaguchi, K.; Ohhira, H.; Hori, K.; Haginiwa, J.; Tetrahedron Lett. 1975, 715.
11. Fonseca, G. O.; Wang, Z.-J.; Namjoshi, O. A.; Deschamps, J. R.; Cook, J. M.; Tetrahedron Lett. 2015, 56, 3052.

12. Wong, W.-H.; Lim, P.-B.; Chuah, C.-H.; Phytochemistry 1996, 41,313; Elderfield, R. C.; Gilman, R. E.; Phytochemistry 1972, $11,339$.

13. Cui, C. B.; Kakeya, H.; Osada, H.; J. Antibiot. 1996, 49, 832; Cui, C.-B.; Kakeya, H.; Osada, H.; Tetrahedron 1996, 52, 12651; Afiyatullov, S. S.; Zhuravleva, O. I.; Chaikina, E. L.; Anisimov, M. M.; Chem. Nat. Compd. 2012, 48, 95.

14. Lerchner, A.; Carreira, E. M.; Chem. - Eur. J. 2006, 12, 8208; Bassleer, R.; Depauw-Gillet, M. C.; Massart, B.; Marnette, J. M.; Wiliquet, P.; Caprasse, M.; Angenot, L.; Planta Med. 1982, 45, 123; Dideberg, O.; Lamotte-Brasseur, J.; Dupont, L.; Campsteyn, H.; Vermeire, M.; Angenot, L.; Acta Crystallogr., Sect. B 1977, B33, 1796.

15. da Silva, J. F. M.; Garden, S. J.; Pinto, A. C.; J. Braz. Chem. Soc. 2001, 12, 273.

16. Marti, C.; Carreira, E. M.; Eur. J. Org. Chem. 2003, 2209.

17. Zhou, F.; Liu, Y.-L.; Zhou, J.; Adv. Synth. Catal. 2010, 352, 1381.

18. Singh, G. S.; Desta, Z. Y.; Chem. Rev. 2012, 112, 6104.

19. Dalpozzo, R.; Bartoli, G.; Bencivenni, G.; Chem. Soc. Rev. 2012, 41, 7247.

20. Ball-Jones, N. R.; Badillo, J. J.; Franz, A. K.; Org. Biomol. Chem. 2012, 10, 5165.

21. Hong, L.; Wang, R.; Adv. Synth. Catal. 2013, 355, 1023.

22. Cheng, D. J.; Ishihara, Y.; Tan, B.; Barbas, C. F.; ACS Catal. 2014, 4, 743.

23. Chen, L.; Yin, X. P.; Wang, C. H.; Zhou, J.; Org. Biomol. Chem. 2014, 12, 6033.

24. Santos, M. M. M.; Tetrahedron 2014, 70, 9735.

25. Dalpozzo, R.; Adv. Synth. Catal. 2017, 359, 1772.

26. Lo, M. M. C.; Neumann, C. S.; Nagayama, S.; Perlstein, E. O.; Schreiber, S. L.; J. Am. Chem. Soc. 2004, 126, 16077.

27. Antonchick, A. P.; Gerding-Reimers, C.; Catarinella, M.; Schuermann, M.; Preut, H.; Ziegler, S.; Rauh, D.; Waldmann, H.; Nat. Chem. 2010, 2, 735.

28. Lu, Y.; Nikolovska-Coleska, Z.; Fang, X.; Gao, W.; Shangary, S.; Qiu, S.; Qin, D.; Wang, S.; J. Med. Chem. 2006, 49, 3759; Ding, K.; Lu, Y.; Nikolovska-Coleska, Z.; Wang, G.; Qiu, S.; Shangary, S.; Gao, W.; Qin, D.; Stuckey, J.; Krajewski, K.; Roller, P. P.; Wang, S.; J. Med. Chem. 2006, 49, 3432; Ding, K.; Wang, G.; Deschamps, J. R.; Parrish, D. A.; Wang, S.; Tetrahedron Lett. 2005, 46, 5949; Ding, K.; Lu, Y.; NikolovskaColeska, Z.; Qiu, S.; Ding, Y.; Gao, W.; Stuckey, J.; Krajewski, K.; Roller, P. P.; Tomita, Y.; Parrish, D. A.; Deschamps, J. R.; Wang, S.; J. Am. Chem. Soc. 2005, 127, 10130.

29. Zhao, Y.; Yu, S.; Sun, W.; Liu, L.; Lu, J.; McEachern, D.; Shargary, S.; Bernard, D.; Li, X.; Zhao, T.; Zou, P.; Sun, D.; Wang, S.; J. Med. Chem. 2013, 56, 5553; Zhao, Y.; Liu, L.; Sun, W.; Lu, J.; McEachern, D.; Li, X.; Yu, S.; Bernard, D.; 
Ochsenbein, P.; Ferey, V.; Carry, J.-C.; Deschamps, J. R.; Sun, D.; Wang, S.; J. Am. Chem. Soc. 2013, 135, 7223; Aguilar, A.; Sun, W.; Liu, L.; Lu, J.; McEachern, D.; Bernard, D.; Deschamps, J. R.; Wang, S.; J. Med. Chem. 2014, 57, 10486; Zhao, Y.; Aguilar, A.; Bernard, D.; Wang, S.; J. Med. Chem. 2015, 58, 1038; Gollner, A.; Rudolph, D.; Arnhof, H.; Bauer, M.; Blake, S. M.; Boehmelt, G.; Cockroft, X. L.; Dahmann, G.; Ettmayer, P.; Gerstberger, T.; Karolyi-Oezguer, J.; Kessler, D.; Kofink, C.; Ramharter, J.; Rinnenthal, J.; Savchenko, A.; Schnitzer, R.; Weinstabl, H.; Weyer-Czernilofsky, U.; Wunberg, T.; McConnell, D. B.; J. Med. Chem. 2016, 59, 10147; Aguilar, A.; Lu, J.; Liu, L.; Du, D.; Bernard, D.; McEachern, D.; Przybranowski, S.; Li, X.; Luo, R.; Wen, B.; Sun, D.; Wang, H.; Wen, J.; Wang, G.; Zhai, Y.; Guo, M.; Yang, D.; Wang, S.; J. Med. Chem. 2017, 60, 2819.

30. David, N.; Pasceri, R.; Kitson, R. R. A.; Pradal, A.; Moody, C. J.; Chem. - Eur. J. 2016, 22, 10867.

31. Suetsugu, S.; Tsukano, C.; Takemoto, Y.; Eur. J. Org. Chem. 2016, 2016, 108.

32. Bian, Z.; Marvin, C. C.; Pettersson, M.; Martin, S. F.; J. Am. Chem. Soc. 2014, 136, 14184.

33. Richter, J. M.; Ishihara, Y.; Masuda, T.; Whitefield, B. W.; Llamas, T.; Pohjakallio, A.; Baran, P. S.; J. Am. Chem. Soc. 2008, 130, 17938.

34. Yang, J.; Wearing, X. Z.; Le Quesne, P. W.; Deschamps, J. R.; Cook, J. M.; J. Nat. Prod. 2008, 71, 1431.

35. Movassaghi, M.; Schmidt, M. A.; Ashenhurst, J. A.; Org. Lett. 2008, 10, 4009.

36. Poriel, C.; Lachia, M.; Wilson, C.; Davies, J. R.; Moody, C. J.; J. Org. Chem. 2007, 72, 2978.

37. Lachia, M.; Poriel, C.; Slawin, A. M. Z.; Moody, C. J.; Chem. Commun. 2007, 286.

38. Deiters, A.; Pettersson, M.; Martin, S. F.; J. Org. Chem. 2006, $71,6547$.

39. Baran, P. S.; Richter, J. M.; J. Am. Chem. Soc. 2005, 127, 15394.

40. Williams, R. M.; Cao, J.; Tsujishima, H.; Cox, R. J.; J. Am. Chem. Soc. 2003, 125, 12172.

41. Takayama, H.; Fujiwara, R.; Kasai, Y.; Kitajima, M.; Aimi, N.; Org. Lett. 2003, 5, 2967.

42. Ito, M.; Clark, C. W.; Mortimore, M.; Goh, J. B.; Martin, S. F.; J. Am. Chem. Soc. 2001, 123, 8003.

43. Powell, N. A.; Kohrt, J. T.; Filipski, K. J.; Kaufman, M.; Sheehan, D.; Edmunds, J. E.; Delaney, A.; Wang, Y.; Bourbonais, F.; Lee, D.-Y.; Schwende, F.; Sun, F.; McConnell, P.; Catana, C.; Chen, H.; Ohren, J.; Perrin, L. A.; Bioorg. Med. Chem. Lett. 2012, 22, 190.

44. Chen, L.; Xie, J.; Song, H.; Liu, Y.; Gu, Y.; Wang, L.; Wang, Q.; J. Agric. Food Chem. 2016, 64, 6508; Li, Z.; Li, Z.; Lin, Y.; Meng, Z.; Ding, G.; Cao, L.; Li, N.; Liu, W.; Xiao, W.; Wu, X.; Xu, J.; Chem. Biol. Drug Des. 2015, 86, 523; Efremov, I. V.; Vajdos, F. F.; Borzilleri, K. A.; Capetta, S.; Chen, H.; Dorff,
P. H.; Dutra, J. K.; Goldstein, S. W.; Mansour, M.; McColl, A.; Noell, S.; Oborski, C. E.; O’Connell, T. N.; O’Sullivan, T. J.; Pandit, J.; Wang, H.; Wei, B.; Withka, J. M.; J. Med. Chem. 2012, 55, 9069; Pumphrey, A. L.; Dong, H.; Driver, T. G.; Angew. Chem., Int. Ed. 2012, 51, 5920; Nagata, K.; Ishikawa, H.; Tanaka, A.; Miyazaki, M.; Kanemitsu, T.; Itoh, T.; Heterocycles 2010, 81, 1791; White, J. D.; Li, Y.; Ihle, D. C.; J. Org. Chem. 2010, 75, 3569; Hart, D. J.; Oba, G.; Tetrahedron Lett. 2007, 48, 7069; Walker, S. J.; Hart, D. J.; Tetrahedron Lett. 2007, 48, 6214; Li, C.; Chan, C.; Heimann, A. C.; Danishefsky, S. J.; Angew. Chem., Int. Ed. 2007, 46, 1444.

45. Bathula, C.; Dangi, P.; Hati, S.; Agarwal, R.; Munshi, P.; Singh, A.; Singh, S.; Sen, S.; New J. Chem. 2015, 39, 9281.

46. Zhang, B.; Zheng, W.; Wang, X.; Sun, D.; Li, C.; Angew. Chem., Int. Ed. 2016, 55, 10435.

47. Mercado-Marin, E. V.; Garcia-Reynaga, P.; Romminger, S.; Pimenta, E. F.; Romney, D. K.; Lodewyk, M. W.; Williams, D. E.; Andersen, R. J.; Miller, S. J.; Tantillo, D. J.; Berlinck, R. G. S.; Sarpong, R.; Nature 2014, 509, 318.

48. Han, S.; Morrison, K. C.; Hergenrother, P. J.; Movassaghi, M.; J. Org. Chem. 2014, 79, 473.

49. Bian, Z.; Marvin, C. C.; Martin, S. F.; J. Am. Chem. Soc. 2013 , 135, 10886.

50. Qi, X.; Bao, H.; Tambar, U. K.; J. Am. Chem. Soc. 2011, 133, 10050.

51. Finefield, J. M.; Williams, R. M.; J. Org. Chem. 2010, 75, 2785.

52. Miller, K. A.; Tsukamoto, S.; Williams, R. M.; Nat. Chem. 2009, 1,63 .

53. Greshock, T. J.; Grubbs, A. W.; Jiao, P.; Wicklow, D. T.; Gloer, J. B.; Williams, R. M.; Angew. Chem., Int. Ed. 2008, 47, 3573.

54. Greshock, T. J.; Williams, R. M.; Org. Lett. 2007, 9, 4255.

55. Greshock, T. J.; Grubbs, A. W.; Williams, R. M.; Tetrahedron 2007, 63, 6124.

56. Artman III, G. D.; Grubbs, A. W.; Williams, R. M.; J. Am. Chem. Soc. 2007, 129, 6336.

57. Greshock, T. J.; Grubbs, A. W.; Tsukamoto, S.; Williams, R. M.; Angew. Chem., Int. Ed. 2007, 46, 2262.

58. Grubbs, A. W.; Artman III, G. D.; Tsukamoto, S.; Williams, R. M.; Angew. Chem., Int. Ed. 2007, 46, 2257.

59. Mercado-Marin, E. V.; Sarpong, R.; Chem. Sci. 2015, 6, 5048.

60. Umehara, A.; Ueda, H.; Tokuyama, H.; Org. Lett. 2014, 16, 2526.

61. Mundal, D. A.; Sarpong, R.; Org. Lett. 2013, 15, 4952.

62. Liu, S.; Hao, X.-J.; Tetrahedron Lett. 2011, 52, 5640.

63. Guo, C.; Song, J.; Luo, S.-W.; Gong, L.-Z.; Angew. Chem., Int. Ed. 2010, 49, 5558.

64. Suarez-Castillo, O. R.; Melendez-Rodriguez, M.; ContrerasMartinez, Y. M. A.; Alvarez-Hernandez, A.; Morales-Rios, M. S.; Joseph-Nathan, P.; Nat. Prod. Commun. 2009, 4, 797.

65. Pettersson, M.; Knueppel, D.; Martin, S. F.; Org. Lett. 2007, 9 , 4623. 
66. Guerrero, C. A.; Sorensen, E. J.; Org. Lett. 2011, 13, 5164.

67. Medeiros, M. R.; Schaus, S. E.; Porco Jr., J. A.; Org. Lett. 2011, 13,4012 .

68. Kolundzic, F.; Noshi, M. N.; Tjandra, M.; Movassaghi, M.; Miller, S. J.; J. Am. Chem. Soc. 2011, 133, 9104.

69. Sun, M.; Hao, X.-Y.; Liu, S.; Hao, X.-J.; Tetrahedron Lett. 2013, $54,692$.

70. Jiang, X.; Yang, J.; Zhang, F.; Yu, P.; Yi, P.; Sun, Y.; Wang, Y.; Org. Lett. 2016, 18, 3154.

71. Baran, P. S.; Maimone, T. J.; Richter, J. M.; Nature 2007, 446, 404.

72. Wearing, X. Z.; Cook, J. M.; Org. Lett. 2002, 4, 4237.

73. Kato, H.; Nakahara, T.; Yamaguchi, M.; Kagiyama, I.; Finefield, J. M.; Sunderhaus, J. D.; Sherman, D. H.; Williams, R. M.; Tsukamoto, S.; Tetrahedron Lett. 2015, 56, 247; Sunderhaus, J. D.; McAfoos, T. J.; Finefield, J. M.; Kato, H.; Li, S.; Tsukamoto, S.; Sherman, D. H.; Williams, R. M.; Org. Lett. 2013, 15, 22; Li, S.; Finefield, J. M.; Sunderhaus, J. D.; McAfoos, T. J.; Williams, R. M.; Sherman, D. H.; J. Am. Chem. Soc. 2012, 134, 788; Kato, H.; Nakamura, Y.; Finefield, J. M.; Umaoka, H.; Nakahara, T.; Williams, R. M.; Tsukamoto, S.; Tetrahedron Lett. 2011, 52, 6923; Finefield, J. M.; Greshock, T. J.; Sherman, D. H.; Tsukamoto, S.; Williams, R. M.; Tetrahedron Lett. 2011, 52, 1987.

74. Patrick, J. B.; Witkop, B.; J. Am. Chem. Soc. 1950, 72, 633.

75. Witkop, B.; Patrick, J. B.; J. Am. Chem. Soc. 1953, 75, 2572.

76. Williams, R. M.; Glinka, T.; Kwast, E.; Tetrahedron Lett. 1989, 30, 5575 .

77. Williams, R. M.; Glinka, T.; Kwast, E.; Coffman, H.; Stille, J. K.; J. Am. Chem. Soc. 1990, 112, 808.

78. Cushing, T. D.; Sanz-Cervera, J. F.; Williams, R. M.; J. Am. Chem. Soc. 1996, 118, 557.

79. Williams, R. M.; Cao, J.; Tsujishima, H.; Angew. Chem., Int. Ed. 2000, 39, 2540.

80. Schendera, E.; Lerch, S.; von Drathen, T.; Unkel, L.-N.; Brasholz, M.; Eur. J. Org. Chem. 2017, 2017, 3134.

81. Zhang, X.; Foote, C. S.; J. Am. Chem. Soc. 1993, 115, 8867.

82. Adam, W.; Ahrweiler, M.; Peters, K.; Schmiedeskamp, B.; J. Org. Chem. 1994, 59, 2733.

83. Garden, S. J.; $10^{\text {th }}$ Brazilian Meeting on Organic Synthesis (BMOS); São Pedro, São Paulo, 2003; Marçal, L. L.; Garden, S. J.; The Oxidation of Indole Derivatives Using Dimethyl Dioxirane; $15^{\text {th }}$ Brazilian Meeting on Organic Synthesis (BMOS), Campos do Jordão, São Paulo, 2013.

84. Murray, R. W.; Jeyaraman, R.; J. Org. Chem. 1985, 50, 2847; Adam, W.; Bialas, J.; Hadjiarapoglou, L.; Chem. Ber. 1991, 124 , 2377; Brik, M. E.; Tetrahedron Lett. 1995, 36, 5519; Ferrer, M.; Gilbert, M.; Sanchez-Baeza, F.; Messeguer, A.; Tetrahedron
Lett. 1996, 37, 3585; Gibert, M.; Ferrer, M.; Sanchez-Baeza, F.; Messeguer, A.; Tetrahedron 1997, 53, 8643; Frohn, M.; Wang, Z.-X.; Shi, Y.; J. Org. Chem. 1998, 63, 6425; Zeller, K.-P.; Kowallik, M.; Haiss, P.; Org. Biomol. Chem. 2005, 3, 2310; Cheshev, P.; Marra, A.; Dondoni, A.; Carbohydr. Res. 2006, 341, 2714; Mikula, H.; Svatunek, D.; Lumpi, D.; Gloecklhofer, F.; Hametner, C.; Froehlich, J.; Org. Process Res. Dev. 2013, 17, 313.

85. Fang, X.; Jin, F.; Jin, H.; von Sonntag, C.; J. Chem. Soc., Perkin Trans. 2 1998, 259.

86. Sagawa, T.; Ohkubo, K.; J. Mol. Catal. A: Chem. 1996, 113, 269.

87. Goeschen, C.; Wibowo, N.; White, J. M.; Wille, U.; Org. Biomol. Chem. 2011, 9, 3380.

88. Dolby, L. J.; Booth, D. L.; J. Am. Chem. Soc. 1966, 88, 1049.

89. Mateo, C. A.; Urrutia, A.; Rodriguez, J. G.; Fonseca, I.; Cano, F. H.; J. Org. Chem. 1996, 61, 810.

90. Garden, S. J.; Correa, M. B.; Pinto, A. C.; Tetrahedron Lett. 2003, 44, 7617.

91. Hsieh, J.-C.; Cheng, A.-Y.; Fu, J.-H.; Kang, T.-W.; Org. Biomol. Chem. 2012, 10, 6404.

92. For previous theoretical studies of dioxirane reactivity with olefins see: Bach, R. D.; Andres, J. L.; Owensby, A. L.; Schlegel, H. B.; McDouall, J. J. W.; J. Am. Chem. Soc. 1992, 114, 7207; Jenson, C.; Liu, J.; Houk, K. N.; Jorgensen, W. L.; J. Am. Chem. Soc. 1997, 119, 12982.

93. Frisch, M. J.; Trucks, G. W.; Schlegel, H. B.; Scuseria, G. E.; Robb, M. A.; Cheeseman, J. R.; Scalmani, G.; Barone, V.; Petersson, G. A.; Nakatsuji, H.; Li, X.; Caricato, M.; Marenich, A.; Bloino, J.; Janesko, B. G.; Gomperts, R.; Mennucci, B.; Hratchian, H. P.; Ortiz, J. V.; Izmaylov, A. F.; Sonnenberg, J. L.; Williams-Young, D.; Ding, F.; Lipparini, F.; Egidi, F.; Goings, J.; Peng, B.; Petrone, A.; Henderson, T.; Ranasinghe, D.; Zakrzewski, V. G.; Gao, J.; Rega, N.; Zheng, G.; Liang, W.; Hada, M.; Ehara, M.; Toyota, K.; Fukuda, R.; Hasegawa, J.; Ishida, M.; Nakajima, T.; Honda, Y.; Kitao, O.; Nakai, H.; Vreven, T.; Throssell, K.; Montgomery Jr., J. A.; Peralta, J. E.; Ogliaro, F.; Bearpark, M.; Heyd, J. J.; Brothers, E.; Kudin, K. N.; Staroverov, V. N.; Keith, T.; Kobayashi, R.; Normand, J.; Raghavachari, K.; Rendell, A.; Burant, J. C.; Iyengar, S. S.; Tomasi, J.; Cossi, M.; Millam, J. M.; Klene, M.; Adamo, C.; Cammi, R.; Ochterski, J. W.; Martin, R. L.; Morokuma, K.; Farkas, O.; Foresman, J. B.; Fox, D. J.; Gaussian 09, Revision C; Gaussian, Inc., Wallingford, CT, 2016.

Submitted: May 16, 2018

Published online: August 9, 2018 